Article

\title{
The Enhancement of Energy Efficiency in a Wastewater Treatment Plant through Sustainable Biogas Use: Case Study from Poland
}

\author{
Adam Masłoń ${ }^{1, *(\mathbb{C}}$, Joanna Czarnota ${ }^{1}\left(\mathbb{D}\right.$, Aleksandra Szaja ${ }^{2}$, Joanna Szulżyk-Cieplak ${ }^{3}{ }^{(D)}$ and \\ Grzegorz Łagód 2,*(D) \\ 1 Department of Environmental Engineering and Chemistry, Rzeszow University of Technology, \\ Powstańców Warszawy 6, 35-959 Rzeszów, Poland; askalucz@prz.edu.pl \\ 2 Faculty of Environmental Engineering, Lublin University of Technology, Nadbystrzycka 40B, 20-618 Lublin, \\ Poland; a.szaja@pollub.pl \\ 3 Fundamentals of Technology Faculty, Lublin University of Technology, Nadbystrzycka 38, 20-618 Lublin, \\ Poland; j.szulzyk-cieplak@pollub.pl \\ * Correspondence: amaslon@prz.edu.pl (A.M.); g.lagod@pollub.pl (G.Ł.); \\ Tel.: +48-17-865-1278 (A.M.); +48-81-538-4322 (G.Ł.)
}

Received: 30 September 2020; Accepted: 13 November 2020; Published: 19 November 2020

\begin{abstract}
The improvement of energy efficiency ensuring high nutrients removal is a great concern for many wastewater treatment plants (WWTPs). The energy balance of a WWTP can be improved through the application of highly efficient digestion or its intensification, e.g., through the introduction of the co-substrates with relatively high energy potential to the sewage sludge (SS). In the present study, the overview of the energetic aspect of the Polish WWTPs was presented. The evaluation of energy consumption at individual stages of wastewater treatment along with the possibilities of its increasing was performed. Additionally, the influence of co-digestion process implementation on the energy efficiency of a selected WWTP in Poland was investigated. The evaluation was carried out for a WWTP located in Iława. Both energetic and treatment efficiency were analyzed. The energy balance evaluation of this WWTP was also performed. The obtained results indicated that the WWTP in Iława produced on average 2.54 GWh per year (7.63 GWh of electricity in total) as a result of the co-digestion of sewage sludge with poultry processing waste. A single cubic meter of co-substrates fed to the digesters yielded an average of $25.6 \pm 4.3 \mathrm{Nm}^{3}$ of biogas (between 18.3 and $32.2 \mathrm{Nm}^{3} / \mathrm{m}^{3}$ ). This enabled covering the energy demand of the plant to a very high degree, ranging from $93.0 \%$ to $99.8 \%$ (98.2\% on average). Importantly, in the presence of the co-substrate, the removal efficiency of organic compounds was enhanced from $64 \%$ (mono-digestion) to $69-70 \%$.
\end{abstract}

Keywords: energy efficiency and security; sustainable energy policy; biogas; co-digestion; sewage sludge

\section{Introduction}

Currently, a sustainable energy policy is the main strategy that has contributed to increasing the global energy and environmental security. One of its pillars is the improvement of the energy efficiency of the existing facilities. The greatest recipient of electricity in cities is the water and sewerage infrastructure, which is responsible for even up to $40 \%$ of total consumption. The entire water management sector corresponds to approximately $4 \%$ of global electricity consumption. The water demand, and thus the amount of wastewater produced are on an increase; therefore, the actions aimed at improving the energy efficiency in the sector are necessary. Importantly, electricity constitutes even up to $40 \%$ of the operating budget of water companies and about $20 \%$ of the costs related to the supply 
and treatment of potable water [1]. Additionally, a further increase in the energy consumption in municipal water supply systems is predicted over the next 15 years, amounting to $60-100 \%$ [2].

Wastewater treatment plants (WWTPs) are an indispensable element of a municipal system. These facilities require the supply of substantial amounts of electricity, which is necessary for wastewater transport, conducting technological processes and the operation of administrative objects [1]. In particular, maintaining the stability of technological processes represents a significant share of the operational costs of an object [3]. Therefore, there is still a need for the solutions improving the efficiency of recovery and production of the electrical and thermal energy at WWTPs. For this reason, innovative wastewater treatment technologies based on nitrogen removal using the Anammox process [4] or granulated activated sludge [5] are being developed. These systems are characterized by lower energy consumption, as compared to the conventional technological solutions. Additionally, the application of various operational and control strategies of the aeration system as well as optimization of energy consumption involving a complex automatic system for data collection, simulation, and prediction, are practiced [6-8].

Another possibility may be the application of waste such as sewage sludge to produce an alternative source of energy (biogas). It is a mixture containing methane $\left(\mathrm{CH}_{4}\right)$ and carbon dioxide $\left(\mathrm{CO}_{2}\right)$ that is generated in the anaerobic digestion process (AD) $[9,10]$. Biogas may be easily used as fuel to generate heat or electricity at WWTPs [11,12]. It should also be noted that the treatment and disposal of sewage sludge is related with a significant financial and energy expenditure for WWTPs. The sludge processing accounts for $40-60 \%$ of the total operational costs [13]. Therefore, over the recent years, the sewage sludge management systems have changed significantly, especially in relation to the circular economy [14].

There are various methods to increase the biogas production in WWTPs. One of the most promising is the implementation of an anaerobic co-digestion process (AcoD). In this strategy, an adequate selected substance is added to the main substrate to improve the AD process efficiency and stability. Thus far, several examples of the AD process application have been reported [15-17]. However, in Poland, the adoption of the co-digestion aimed at balancing the $\mathrm{C} / \mathrm{N}$ ratio to increase the biogas production is not widespread mainly due to numerous operational difficulties. Commonly, the results of modeling and lab-scale investigations do not comply with a technical scale. Operators must take into account the financial aspect, process efficiency, as well as legal regulations. The novel aspect of the study involved presenting the complex and multi-threaded analysis of implementation the co-digestion strategy of a selected WWTP. The evaluation includes both the energetic and technological aspects. The presented information might contribute to increasing the knowledge in this field and might allow for more common use of this strategy under Polish conditions. Thus far, such evaluation has not been considered in the case of the Polish WWTPs. The presented results and experiences constitute an innovative material in the field of renewable energy sources in a wastewater industry. The successful application of this strategy depends on a variety of factors, including the type and dose of co-substrate as well as the appropriately selected operating conditions. Importantly, supplementation of the feedstock with an improper substrate might bring many negative effects, contributing to the breakdown of the process and the decreasing of biogas production [18]. Importantly, the AD process might be implemented at the WWTPs with the daily flow greater than $20,000 \mathrm{~m}^{3} / \mathrm{d}$. However, for smaller WWTPs, this technology might be unprofitable. For such facilities, the cost related with construction and maintenance of anaerobic digesters is significant. Importantly, in this case, sewage sludge might be dehydrated (total solids content (TS) $>15 \%$ ) and then transported to a local High-Solid Anaerobic Digestion Reactor, where it could be treated/digested with other biodegradable wastes. This strategy might be considered as a cost-effective solution for small WWTPs [19].

Thus, the actions aimed at implementing the low-energy or passive WWTPs are being taken [20]. These result in a reduction of the operational costs, improvement of stability and reliability of the wastewater treatment processes, as well as mitigation of the WWTP impact on the aquatic environment [21-23]. 
In the present study, the overview of energetic aspect of WWTP functioning in Poland was shown. The authors indicated the energy consumption at individual stages of WWTP along with the possibilities of increasing the energy efficiency. Moreover, the current situation in terms of biogas production and its utilization at Polish WWTPs was evaluated. Additionally, the influence of the implementation of a co-digestion process on the energy efficiency of a selected WWTP in Poland was investigated in this study. For this purpose, the energy consumption at individual stages of treatment was analyzed. An energy balance evaluation of WWTP in Iława was performed as well. The justifiability of using the biogas from the co-digestion of sewage sludge in terms of improving the energy efficiency was analyzed. By investigating the energy intensity of processes and biogas usage within WWTPs, conducting the research on the topic was justified. Attention was also drawn to the energy potential of the sewage sludge generated in the Polish WWTPs, taking into account the possible increase of the biogas production.

\section{Energy Intensity and Biogas Energy Technology of WWTPs}

\subsection{Energy Consumption in the Technological Wastewater Treatment Processes}

Electricity is used in all stages of treatment that involve electric drive systems in the form of electric engines. Electric engines are used for compressing, pumping, and transporting liquids and gases using pumps, fans, and compressors; moreover, they are used in mixers, presses, and other devices for processing the wastes separated from wastewater (screenings, sand, and sewage sludge) [24]. Electric drive systems are employed in each stage of wastewater treatment; thus, all technological operations such as mixing, aeration, and pumping, being part of the wastewater treatment system, affect the consumption of electricity [7]. In turn, the thermal energy is used in the sewage sludge processing - in digesters, sludge dryers, etc. In a wastewater treatment plant, electrical and thermal energies are also used for the social needs of employees, heating of technical and administrative buildings, lighting the premises, etc. Therefore, the wastewater treatment system should also be considered as a thermal-energetic system $[1,2,21]$. An exemplary structure of electricity consumption in a WWTP located in southern Poland is presented in Figure 1. The analysis of electricity consumption in particular technological elements of the WWTP enables to determine the energy consumption structure and thus its rationalization [2].

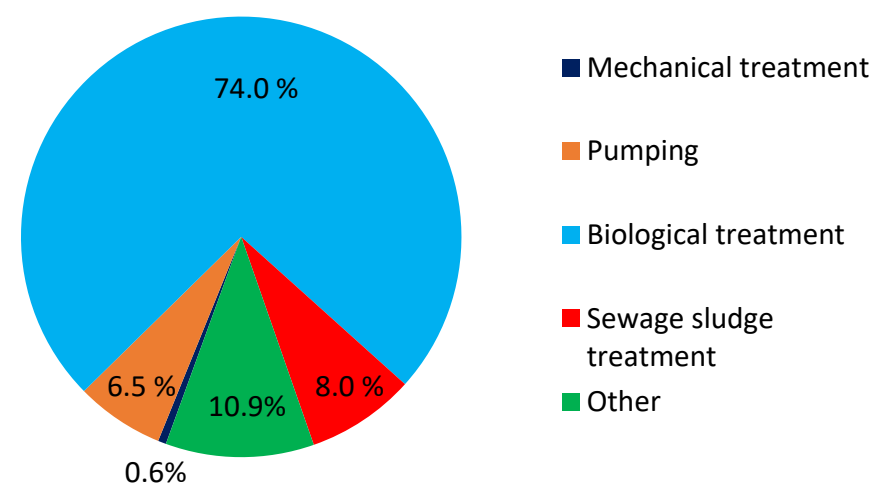

Figure 1. Electricity consumption in particular parts of a wastewater treatment plant (WWTP) located in southern Poland [based on authors' own work].

The municipal wastewater treatment process involves two stages-mechanical (removal of floating, and suspended solids) and biological treatment (removal of organic pollutants, as well as nitrogen and phosphorus compounds). Additionally, each stage includes wastewater pumping. The mechanical treatment involves the removal of screenings, mineral, and organic solids. These processes are realized in screens, grit chambers, as well as primary settling tanks. They are characterized by a relatively low consumption of electricity and usually consume less than $1 \%$ of the energy used by the entire 
WWTP [25]. It mainly depends on the employed devices and characteristic of influent wastewater as well as the adopted operating conditions. The consumption of energy for the pumping of raw wastewater is determined by the pumping height and ranges from 0.02 to $0.37 \mathrm{kWh} / \mathrm{m}^{3}$ [26]. In the biological treatment of wastewater, the aeration of nitrification chambers is the most energy-intensive process, requiring between 0.18 and $0.8 \mathrm{kWh} / \mathrm{m}^{3}$; thus, it consumes of up to $75 \%$ of energy within this stage of treatment $[7,21]$. The consumption of energy for aeration can be reduced through smart control [7]. Apart from the aeration, the mixing of activated sludge and sludge recirculation also require substantial quantities of energy. A literature review indicates that the conventional activated sludge process consumes between 0.27 and $0.6 \mathrm{kWh} / \mathrm{m}^{3}$ [24].

An inherent part of a WWTP is the processing and disposal of sewage sludge. The energy demand of sludge processing is related with the WWTP type of employed technology as well as the type of devices. The energy demand of sludge management in a WWTP ranges from 5 to $30 \%$ of the energy consumed in a plant [20]. Depending on the WWTP size, the thickening, aerobic or anaerobic stabilization (digestion) and sludge dewatering processes are involved. At large WWTPs, the anaerobic digestion is the most widely applied process, and additional drying or combustion of sewage sludge are also performed. The biogas produced in the AD process may be used as a replacement for a fossil fuel $[9,27,28]$. Its generation from sewage sludge for energy production is profitable at the WWTPs receiving $8000-10,000 \mathrm{~m}^{3}$ of wastewater per day. Usually, the sludge management operates on a cyclic basic; thus, it can be easily optimized in terms of the electrical or thermal energy consumption.

Figure 2 presents a scheme of a conventional WWTP $>100,000$ PE size. Therein, the objects with high electricity consumption as well as the devices potentially generated and recovered electrical and/or thermal energy are illustrated. The most significant energy consumption occurs during the activated sludge aeration (A), pumping (B and D), and mixing of activated sludge (C). Moreover, energy consumption is related with maintaining optimum temperature in digesters $(E)$ and the drying of sewage sludge (F). In turn, the energy gain in a WWTP involves the application of biogas for the production of electricity in Combined Heat and Power (CHP) - $(\mathrm{Ga})$ generators/co-generators and thermal energy generation in boilers $(\mathrm{Gb})$ as well as production of thermal energy from the combustion of dried sludge $(\mathrm{H})$.

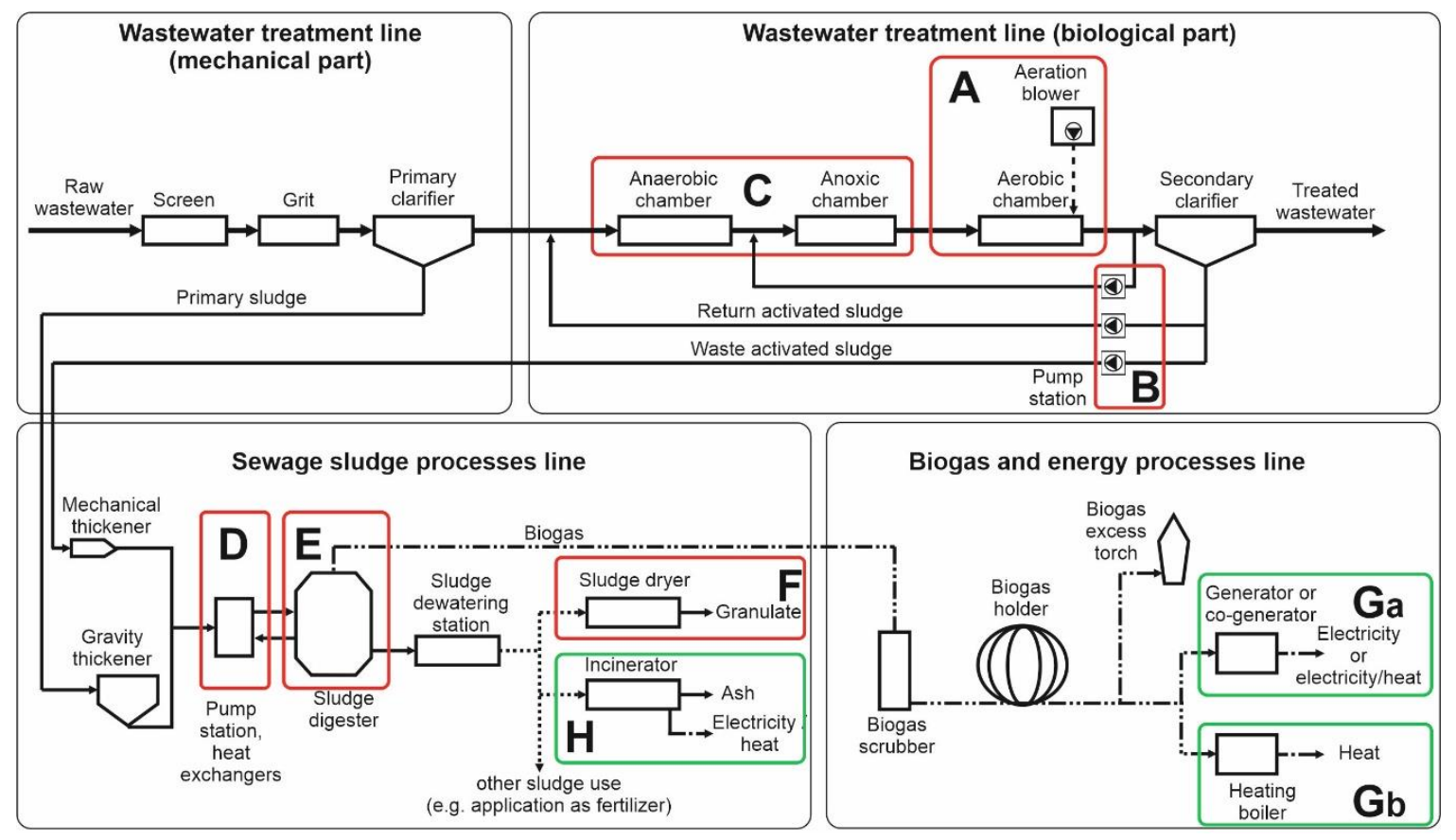

Figure 2. Scheme of a WWTP showing the objects contributing to the consumption and gains of electrical and thermal energy (authors' own elaboration based on Dymaczewski and Szulc [29]). 
However, sewage sludge has the greatest potential of energy recovery that can positively influence the energy balance of the entire plant [30]. The recovery of energy from sewage sludge can be performed in two ways. The first involves the application of the biogas produced in the anaerobic digestion process, whereas in the second, sewage sludge is combusted in thermal installations. In some cases, sewage sludge has to be dried beforehand, and external fuel has to be supplied, which negatively impacts the process economy. It is also possible to employ a solar dryer.

The energy savings in WWTPs are mainly connected with the improvement or replacement of the energy-intensive devices (pumps, mixers, air blowers) as well as the implementation of smart control and monitoring systems for the wastewater treatment processes [7]. Furthermore, the possibility of electrical and thermal energy production from sewage sludge (e.g., thermal hydrolysis, digestion, co-digestion, sludge combustion), as well as the recovery of energy from wastewater (heat pumps), should be also considered. The application of innovative wastewater treatment and sewage sludge processing methods with a simultaneous rationalization of energy consumption enables achieving the self-sufficiency of a facility in terms of the energy demand. However, in order to meet the objectives of sustainable development and the circular economy, the production of electrical and thermal energy exceeding the needs of the object is required. The surplus energy can be transmitted to a distribution network. Additionally, intensification of the electricity production can be achieved through the application of photovoltaic panels, as well as wind and water turbines localized at the area of the WWTP [2]. The most common potential energy savings in a WWTP are presented in Table 1.

Table 1. Distribution of energy consumption and potential for energy saving in a selected WWTP with an activated sludge system [31].

\begin{tabular}{cccc}
\hline Treatment Stage & $\begin{array}{c}\text { Share in Energy } \\
\text { Consumption [\%] }\end{array}$ & Potential for Energy Saving & Comments \\
\hline $\begin{array}{c}\text { Wastewater Pumping } \\
\text { (Pumping Station) }\end{array}$ & 10 & $\begin{array}{c}5-10 \% \text { through the modification } \\
\text { of the existing pumps; up to } 30 \% \\
\text { through better conservation and } \\
\text { adjustment to the throughput }\end{array}$ & $\begin{array}{c}\text { depending on the } \\
\text { topography where } \\
\text { WWTP is located }\end{array}$ \\
\hline $\begin{array}{c}\text { 20-50\% through the optimization } \\
\text { of technological parameters, } \\
\text { optimization of aeration and } \\
\text { mixing in biological reactors } \\
\text { implementation of online control }\end{array}$ & $\begin{array}{c}\text { mainly pertains to } \\
\text { aeration and mixing in } \\
\text { the reactor }\end{array}$ \\
$\begin{array}{c}\text { Processing and Disposal } \\
\text { of Sewage Sludge } \\
\text { (Dewatering and } \\
\text { Transport of Sludge) }\end{array}$ & 55 & $\begin{array}{c}\text { 30\% of energy efficiency can be } \\
\text { achieved through the application } \\
\text { of mesophilic anaerobic digestion } \\
\text { with implementation of } \\
\text { additional substrate }\end{array}$ & $\begin{array}{c}\text { determined by operating } \\
\text { conditions and the type } \\
\text { of selected substrate }\end{array}$ \\
\hline
\end{tabular}

In addition to the above-mentioned examples, some WWTPs also use advanced technologies to enhance the energy efficiency. The pre-processing of sludge (conditioning and disintegration) or the anaerobic stabilization process may improve the energy efficiency of WWTPs even by up to $50 \%$. Further implementation of integrated co-digestion processes and highly efficient co-generation may increase the efficiency by up to $80 \%$ [31]. However, due to significant investment costs, these technologies are not implemented in many Polish WWTPs.

\subsection{Biogas Production from Sewage Sludge in a Wastewater Treatment Plant}

Taking into account the energy balance of a wastewater treatment plant, the anaerobic digestion of sewage sludge is the most beneficial solution. The biogas from sewage sludge can be employed for the production of heat, as well as mechanical and electrical energy. The typical methods of biogas utilization include the following: (1) combustion in heating boilers producing the heat for the heating, (2) combustion in gas engines coupled with the generators producing mechanical energy 
powering pumps, and (3) combustion in gas engines or gas turbines coupled with power generators, producing electricity powering the devices in a WWTP. Each of the above-mentioned methods also generates thermal energy, which may be used for technological purposes (e.g., maintaining appropriate temperature in digesters) or hot water preparation (CHP process) $[9,10,27,32,33]$. However, the biogas application depends mainly on its characteristics. It consists of $60-67 \%$ methane, $30-33 \%$ carbon dioxide, $1-2 \%$ hydrogen, and $0-3 \%$ nitrogen $(v / v)$. Moreover, biogas can additionally contain small amounts of hydrogen sulfide, ammonia, and hydrocarbons [34]. Nevertheless, the detailed composition is determined by the properties of sewage sludge and operational parameters. Depending on the methane content in the biogas, its calorific value approximates $23.4 \mathrm{MJ} / \mathrm{m}^{3}$, while the removal of carbon dioxide and other pollutants further improves this value [9].

Currently, one of the priorities in anaerobic digestion technology is the intensification of biogas production as well as improvement of the process stability. Those might be achieved through the application of a properly selected substrate to the sewage sludge [21,35-37]. Moreover, the utilization of various pre-treatment methods including mechanical (ultrasonic, microwave, electro-kinetic and high-pressure homogenization), thermal, chemical (acidic, alkali, ozonation, Fenton and Fe(II)-activated persulfate oxidation) as well as biological approaches (enzyme application) has been reported [38-43].

However, the co-digestion of sewage sludge with other wastes is considered as the most promising solution. It is defined as an anaerobic simultaneous degradation of two or more appropriately selected substrates [15,36]. As compared to the previously mentioned pre-treatment methods, it is characterized by relatively low cost of implementation. Moreover, it should be noted that in the co-digestion process, various organic wastes are used as co-substrates. In this way, an increase in biogas production as well as management of various groups of waste may be achieved. Importantly, this strategy involves the untapped biogas potential of the existing digesters [44]. Therefore, the AcoD process strategy is consistent with the principles of sustainable development [45-47].

As opposed to mono-digestion, co-digestion presents numerous advantages, such as improvement of the biogas and methane production, amelioration digestion efficiency, as well as enhancement of the process stability. However, a crucial element is the selection of substrates with complementary composition to the main feedstock. These components should ensure the required nutrient balance in feedstock [48] and improve the $\mathrm{C} / \mathrm{N}$ ratio as well as dilute inhibitory or toxic compounds in the main feedstock $[35,48,49]$. Additionally, wastes with high biogas potential and significant micro and macro elements content are preferred. Sewage sludge is characterized by an unfavorable $\mathrm{C} / \mathrm{N}$ ratio, low dry matter content, as well as relatively low biogas potential $[15,50,51]$. Therefore, it is should be co-digested with the substrates containing significant amounts of easily biodegradable organic matter and characterized by high buffer capacity. The presence of various micro and macro elements, deficient in sewage sludge, is also highly demanded. Moreover, the cost of transport and possible pre-treatment of substrates should be considered before the implementation of this strategy.

Taking into consideration the above-mentioned facts, the most widespread is the application of the following substrates: organic fraction of municipal solid waste (OFMSW); fat, oil, and grease wastes (FOG); various agro-industrial by-products (e.g., fruit and vegetable waste, glycerol and slaughterhouse wastes) [52,53]. Among the mentioned substrates, the use of wastes characterized by significant fat content is of great interest. These by-products originate from the food industry, including slaughterhouses, meat processing plants, and dairies, as well as facilities producing fats and oils. Moreover, this waste can also be sourced from restaurants as well as municipal and industrial WWTPs, in which flotates are separated $[35,36,54,55]$. Their widespread use in co-digestion with sewage sludge is due to the high biogas potential $\left(0.7\right.$ to $\left.1 \mathrm{~m}^{3} / \mathrm{kg} \mathrm{VS}\right)$, significant content of biodegradable organic matter, and a beneficial $\mathrm{C} / \mathrm{N}$ ratio $[50,55,56]$. However, the application of this co-substrate may cause several operational problems related to the clogging of digesters and pipes as well as the appearance of foam in the anaerobic reactor $[57,58]$. Additionally, the inhibition of long-chain fatty acids (LCFA) may be observed in the FOG presence [56]. However, there are many successful examples of use of such wastes in co-digestion with sewage sludge in terms of biogas and energy production $[35,50,56,59,60]$. 
Table 2 presents certain biogas properties with the operational conditions of various organic substances characterized by significant fat content that can be co-digested with sewage sludge. These data pertain not only to the laboratory studies but also to the full-scale implementation of co-digestion [32,61].

Table 2. The maximum biogas production and methane content in biogas for different organic co-substrates [60].

\begin{tabular}{cccc}
\hline Organic Co-Substrates & $\begin{array}{c}\text { Maximum Biogas Production } \\
(\mathbf{m L} / \mathbf{g} \text { VS) }\end{array}$ & $\begin{array}{c}\text { Methane Content } \\
\text { in Biogas (\%) }\end{array}$ & $\begin{array}{c}\text { Content of Substrate in } \\
\text { the Feedstock }(\boldsymbol{v} / \boldsymbol{v} \%)\end{array}$ \\
\hline Waste meat & 170.3 & 76 & 3 \\
Soapstock & 117.17 & 73 & 10 \\
By-products after & 99.91 & 72 & 10 \\
biodiesel production & 95.69 & 73 & 0.5 \\
Molasses & 88.68 & 70 & 3 \\
Waste from fat separator & & & 3 \\
\hline
\end{tabular}

\section{Biogas Utilization at WWTPs in Poland}

In recent years, a dynamic development and expansion of sewerage networks and municipal WWTPs has been observed in Poland. This leads to the generation of substantial amounts of municipal sewage sludge. According to the statistical data, 447,000 Mg TS of municipal sewage sludge was produced in Poland in 2003, whereas in 2018, it increased to 583,000 Mg TS [62]. The principles for the processing and final management of municipal sewage sludge are regulated both by the EU and Polish law [63-66].

The current energy demand of WWTPs in Poland is approximately 1 TWh/year [24]. Compared to other countries, it constitutes a relatively low value. The consumption of electricity by all WWTPs in Europe was calculated as $27 \mathrm{TWh} /$ year [67]. A constant development of the municipal infrastructure indicates an increase in the energy consumption for WWTP in Poland, even up to $5.5 \mathrm{TWh} /$ year, which will comprise ca. 2.5-3.5\% of the total country electricity demand [2].

Currently, there are almost 2500 WWTPs in Poland; however, only 140 are equipped with the installations to conduct the anaerobic digestion of sewage sludge (Figure 3 ). This means that only $6 \%$ of the WWTPs operating in Poland are capable of producing biogas. The total volume of digesters in all WWTPs is estimated at 800,000-900,000 $\mathrm{m}^{3}$. Nevertheless, not every plant utilizes the produced biogas for the generation of thermal and/or electrical energy. Only 112 plants are equipped with biogas-powered generators, a single plant boasts a steam turbine, and another is equipped with a thermoelectric generator for power generation from the exhaust gases [68]. The total output of the power generators in Polish WWTPs amounts to $72 \mathrm{MW}_{\mathrm{el}}$. The production of electricity in WWTPs equals 336.5 GWh (Figure 4). In 2018, the total electricity demand in Poland amounted to $172 \mathrm{TWh} /$ year [62]. On the basis of the total amount of processed sludge in the AD processes, it can be stated that the energy potential of sewage sludge is used in less than 40\% [69]. For comparison, in Croatia, approximately $30 \%$ of sewage sludge is converted into biogas through the AD process [70]. Nevertheless, there is still a potential for the construction of anaerobic digesters in Poland. It is estimated that as many as 170 installations for biogas production may be built in the Polish WWTPs [69]. This potential can be increased further through the application of new technologies, leading to the enhancement of the biogas production (e.g., thermal hydrolysis). That may constitute over $1 \%$ of energy production in Poland, which would cover the total energy demand of all the currently operated WWTPs. It is estimated that even up to $0.5-0.7$ billion $\mathrm{Nm}^{3}$ of the biogas can be generated at WWTPs [68]. Comparing these data to the natural gas production in Poland (4.6 billion $\mathrm{Nm}^{3}$ in 2018) [71], it constitutes a substantial amount of generated fuel. In turn, the total natural gas consumption in Poland amounts to 19.7 billion $\mathrm{Nm}^{3}$ (data for 2018) [72]. In addition, the biogas installations in WWTPs can act as storage power stations due to the ease of biogas storage; in addition, its production is stable and related to the economic activity in urbanized areas. 


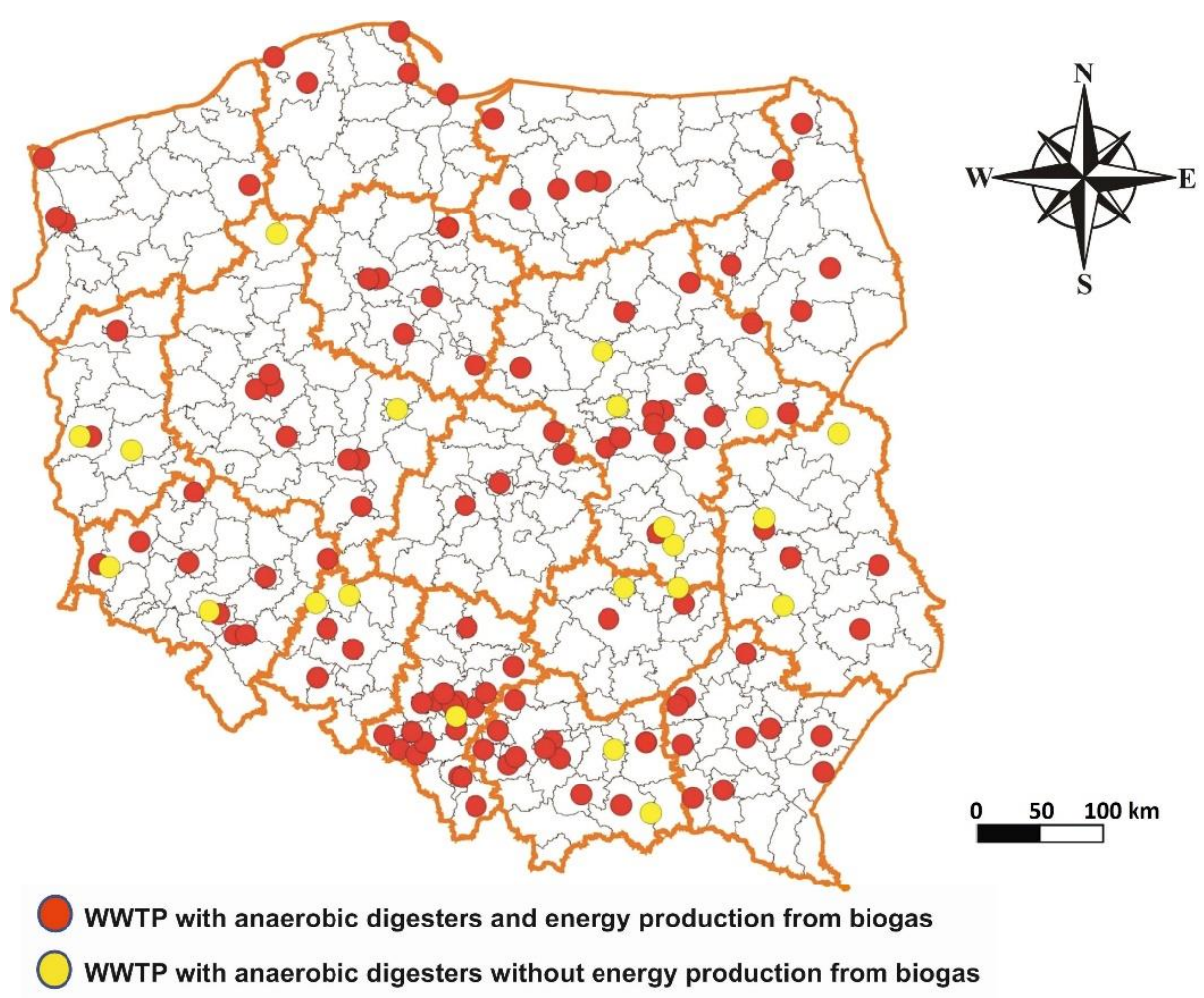

Figure 3. WWTPs in Poland utilizing the anaerobic digestion of sewage sludge, data from [69].

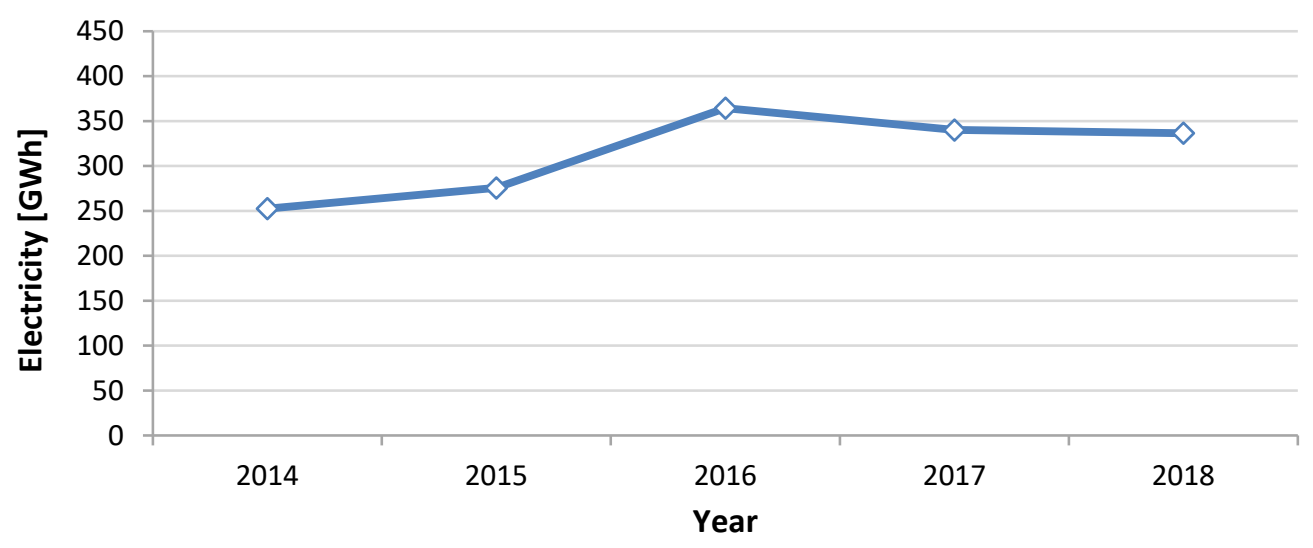

Figure 4. Production of electricity from biogas in WWPS in 2014-2018, authors' own elaboration based on statistical data [62].

\section{Materials and Methods}

\subsection{Description of the Plant}

\subsubsection{General Characteristics of the Wastewater Treatment Plant in Iława}

The WWTP in Iława involves mechanical and biological treatments. It is located in the warmińsko-mazurskie voivodeship (northeast of Poland). This facility serves approximately 32.5 thousand inhabitants. It was designed for an average daily wastewater flow of $26,940 \mathrm{~m}^{3} / \mathrm{d}$ (maximum daily flow-31,115 $\mathrm{m}^{3} / \mathrm{d}$ ) and population equivalent equal to 154,117 . The WWTP in Iława was constructed in 1991 and has been modernized several times. The mechanical part of the WWTP includes screens, grit chambers, and grease traps as well as primary clarifiers. In turn, the biological treatment is conducted in nitrification and denitrification chambers as well as the chambers for biological 
phosphate removal. Moreover, this part includes radial secondary clarifiers. The sludge management line comprises raw sludge pumping stations, two gravitational thickeners for the primary sludge, a mechanical thickening station for excess sludge from secondary clarifiers (two drum thickeners) with the output of $Q_{\mathrm{v}}=12 \mathrm{~m}^{3} / \mathrm{h}$, two closed digesters with the capacity of $1885 \mathrm{~m}^{3}$ each, sludge decanter centrifuge for dewatering the digested sludge, and a solar sludge dryer. The treated effluent is discharged to the Iławka river, which is the right-hand tributary of the Drweca river (Baltic Sea catchment) (Figure 5).

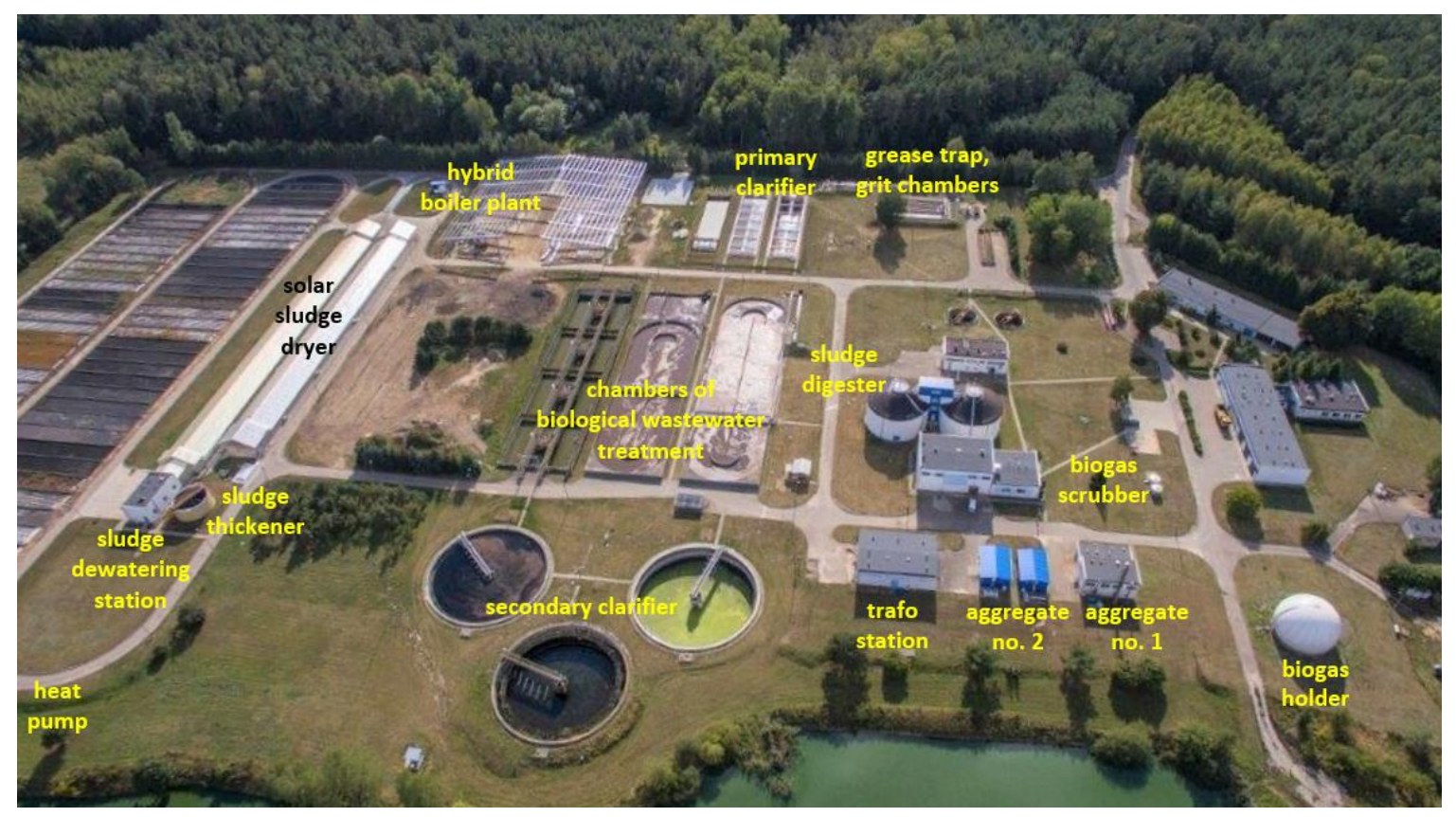

Figure 5. WWTP in Iława (authors' own elaboration).

The treatment plant receives municipal wastewater, which is a mixture of domestic and industrial wastewater. The wastewater from a poultry slaughterhouse and processing plant (about $900 \mathrm{~m}^{3} / \mathrm{d}$ ), cellulose processing factory (about $250 \mathrm{~m}^{3} / \mathrm{d}$ ) as well as a potato processing facility (approximately $42,000 \mathrm{~m}^{3}$ over a two-month campaign) are discharged to the Iława WWTP.

As is shown in Table 3, it was observed that the wastewater characteristics significantly differed in 2017-2019. This was caused by the seasonal discharge of industrial wastewater. Moreover, it should be noticed that Iława is a tourist city. This fact may also influence significant fluctuations in the quantity and quality of the influent wastewater. 
Table 3. Characteristic of the influent wastewater in 2017-2019.

\begin{tabular}{cccccc}
\hline \multicolumn{1}{c}{ Hydraulic Load } \\
Parameter & & Minimum & Maximum & Average & SD \\
\hline Total wastewater, $\mathrm{m}^{3} / \mathrm{d}$ & & 4886.0 & 8816.0 & 6176.0 & 837.0 \\
\hline \multicolumn{2}{c}{ Physicochemical Parameters } & & & \\
\hline Parameter & & Minimum & Maximum & Average & SD \\
\hline \multirow{2}{*}{ Biochemical oxygen demand (BOD 5$)$} & $\mathrm{mg} / \mathrm{L}$ & 519.5 & 1220.0 & 752.4 & 165.4 \\
\cline { 2 - 6 } & $\mathrm{kg} / \mathrm{d}$ & 2908.7 & 6736.0 & 4613.9 & 947.1 \\
\hline \multirow{2}{*}{ Chemical oxygen demand (COD) } & $\mathrm{mg} / \mathrm{L}$ & 1057.0 & 2301.0 & 1559.4 & 320.8 \\
\cline { 2 - 6 } & $\mathrm{kg} / \mathrm{d}$ & 6116.9 & $15,108.4$ & 9595.5 & 2032.5 \\
\hline \multirow{2}{*}{ Total suspended solids (TSS) } & $\mathrm{mg} / \mathrm{L}$ & 182.5 & 815.0 & 542.8 & 139.5 \\
\cline { 2 - 6 } & $\mathrm{kg} / \mathrm{d}$ & 1119.3 & 5220.4 & 3353.9 & 926.4 \\
\hline \multirow{2}{*}{ Total nitrogen (TN) } & $\mathrm{mg} / \mathrm{L}$ & 68.2 & 128.5 & 101.4 & 14.8 \\
\cline { 2 - 6 } & $\mathrm{kg} / \mathrm{d}$ & 453.2 & 992.3 & 623.6 & 101.1 \\
\hline \multirow{2}{*}{ Total phosphorous (TP) } & $\mathrm{mg} / \mathrm{L}$ & 8.9 & 69.3 & 16.0 & 10.0 \\
\cline { 2 - 6 } & $\mathrm{kg} / \mathrm{d}$ & 62.4 & 338.6 & 96.5 & 48.9 \\
\hline
\end{tabular}

\subsubsection{Sludge-Energy System in the WWTP}

In the Iława WWTP, the anaerobic digestion process is conducted in two anaerobic digesters under mesophilic conditions $\left(37-39^{\circ} \mathrm{C}\right.$ ) at hydraulic retention time (HRT) of $37 \mathrm{~d}$. The generated biogas after scrubbing is stored in a biogas holder with the capacity of $1040 \mathrm{~m}^{3}$. It is used for the co-generation of electrical and thermal energy. The WWTP comprises three co-generators (CHP system)-two with the output of $253 \mathrm{~kW}$ of electricity and $318 \mathrm{~kW}$ of thermal energy (Petra 300, Elteco) as well as a single generator producing $190 \mathrm{~kW}$ of electricity and $250 \mathrm{~kW}$ of thermal energy (Gesco), with the combined output of $0.696 \mathrm{MW}$ (electricity) and 0.881 MW (thermal energy). The produced electricity is used to conduct the treatment processes (powering pumps, air blowers, etc.). In turn, the produced thermal energy is used for maintaining temperature in digesters as well as for heating the social buildings. Moreover, the surplus of thermal energy is employed for heating the floor (with the total surface area of $2800 \mathrm{~m}^{2}$ ) in the solar dryer that comprises two buildings. Additionally, the heat generated by the heat pump integrated with secondary clarifiers is used for drying sewage sludge (Figure 6).

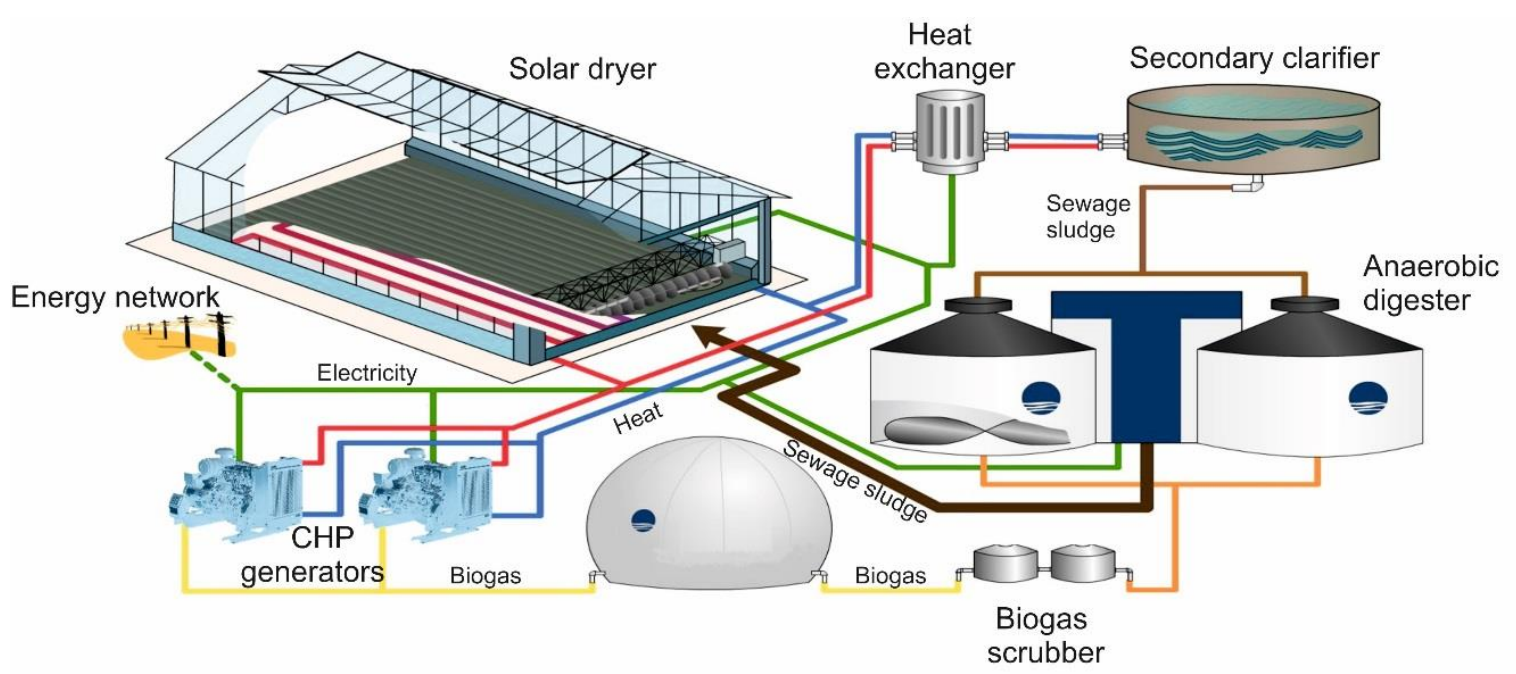

Figure 6. Scheme of energy usage in the WWTP in Iława. 


\subsection{Methods}

The analysis of sludge and biogas-energy management was carried out on the basis of the data obtained from a technical scale (the Iława WWTP) for the period from January 1st, 2017 to December 31st, 2019. In this study, the amount of generated sewage sludge and the produced biogas in relation to the volume of wastewater and the load of pollutants flowing into the wastewater treatment plant were analyzed. In order to perform this evaluation, the basic parameters pertaining to the production of sludge, biogas, and electricity were used. The following parameters were examined: biogas yield, VS removal, OLR and energy consumption at individual stages. The influence of the $\mathrm{BOD}_{5}$ load in the influent and OLR of the digester on the amount of biogas yield from sewage sludge was examined. Moreover, the analysis of the impact of the co-substrates on biogas in digestion process production was performed. The facility's energy consumption and an energy balance were also carried out in the biogas and energy system of the wastewater treatment plant in Ilawa.

Statistical analyses were performed to identify the major cause and effect relationships. Univariate linear correlations were used to simplify the analyses (Pearson's coefficient $r$ ). A distribution-free statistical method was used, because a normal distribution was not obtained for many of the parameters examined.

\section{Results and Discussion}

In the Iława WWTP, anaerobic digesters are supplied by the mixture of primary and waste sludge with the additive of co-substrates. The poultry processing wastes are used as additional components. The amount of generated sewage sludge depends on the composition and volume of influent wastewater as well as the adopted treatment technology [73]. Due to the significant share of industrial wastewater (poultry, cellulose, and potato processing wastewater), the amount of sewage sludge was varied notably. It amounted to $0.42-1.27 \mathrm{~kg} \mathrm{TS} / \mathrm{m}^{3}$ for primary sludge (PS) and $0.19-1.08 \mathrm{~kg} \mathrm{TS} / \mathrm{m}^{3}$ for excess sludge (ES). In the analyzed period of 2017-2019, the mean annual amount of produced sewage sludge amounted to $23,834 \mathrm{~m}^{3}$ and $15,725 \mathrm{~m}^{3}$ for PS and ES, respectively. In turn, the total amount of sludge directed to digesters reached $1510.8 \mathrm{Mg}$ TS/year and $1467.0 \mathrm{Mg}$ TS/year for PS and ES, respectively. The total solids content (TS) in the primary and waste sludge amounted to $6.5 \pm 2.0 \%$ and $9.4 \pm 1.8 \%$, respectively. The poultry fat waste was added to the feedstock digester as an emulsion with dry mass content of $11.5 \%$. The daily volume of this component ranged from 9.8 to $22.6 \mathrm{~m}^{3} / \mathrm{d}$, with the average value of $14.7 \pm 3.4 \mathrm{~m}^{3} / \mathrm{d}$. The detailed data of the co-substrate introduced into digesters is presented in Figure 7.

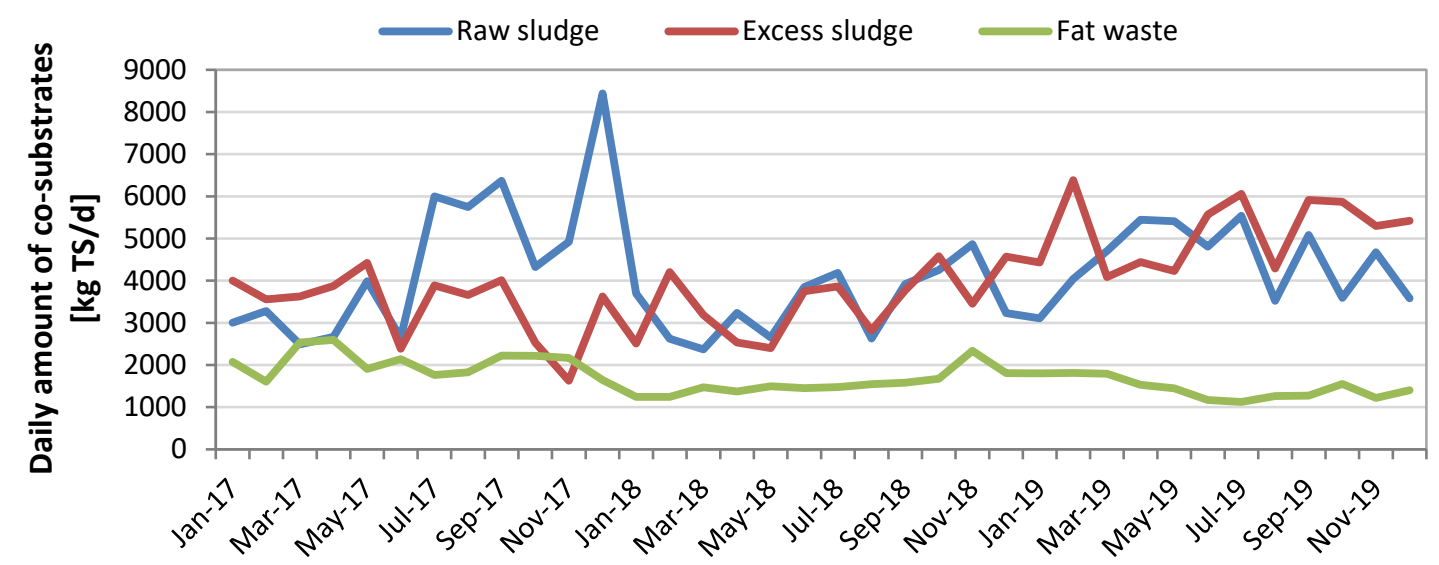

Figure 7. The daily flow of substrates supplied to the digester in the Iława WWTP. 
In the presence of a co-substrate, the removal efficiency of organic compounds increased from approximately $64 \%$ (mono-digestion of sewage sludge) to $69-70 \%$. Simultaneously, the sludge dewatering level decreased from $21 \%$ to $18 \%$, while the polymer consumption remained unchanged.

The amount of introduced fat waste was continuously monitored and modified in order not to exceed the level of $4.8 \mathrm{~kg} \mathrm{VS} /\left(\mathrm{m}^{3} \cdot \mathrm{d}\right)[15,74]$. The share of co-substrate in the feedstock was maintained at the level from 6.2 to $21.2 \%$ and it depended on the amount of sewage sludge (Figure 8 ). The dosing of co-substrate should be constantly controlled due to the possibility of biogas composition deterioration (increase the $\mathrm{CO}_{2}$ content) and operational problems, especially during the dewatering of digested sludge $[55,75]$. It is assumed that the share of additional substrates for co-digestion with sewage sludge should not exceed 30\% [76]. During operation, OLR ranged from 1.74 to $3.64 \mathrm{~kg} \mathrm{VS} /\left(\mathrm{m}^{3} \cdot \mathrm{d}\right)$, while HRT was maintained at 37 days. For comparison, in the Millbrae WPCP (USA) plant with similar parameters $\left(Q_{\text {dav }}=7570 \mathrm{~m}^{3} / \mathrm{d}\right)$, sewage sludge and fat waste were processed in two digesters $\left(1900 \mathrm{~m}^{3}\right.$ each) at HRT of 38-58 d [32].



Figure 8. The percentage share of particular co-substrates in the feedstock supplied digester in the Iława WWTP.

The monthly biogas yield in digesters ranged from 78,110 to $103,895 \mathrm{Nm}^{3}\left(93,204 \mathrm{Nm}^{3} / \mathrm{month}\right.$, on average). In the autumn months, a greater amount of biogas was produced than in the remaining period. However, no seasonal trend was observed over the previous three years. The daily amount of the produced biogas ranged from $2774.4-3353.5 \mathrm{Nm}^{3} / \mathrm{d}$, with the mean value of $3063.5 \pm 168.9 \mathrm{Nm}^{3} / \mathrm{d}$ (Figure 9). In the considered period, 0.220 to $0.451 \mathrm{Nm}^{3}$ was obtained from $1 \mathrm{~kg}$ TS of all substrates introduced to digesters. The mean unit yield of biogas amounted to $0.321 \mathrm{Nm}^{3} / \mathrm{kg}$ TS. In relation to the volume of co-substrates introduced to digesters, a single cubic meter yielded $25.6 \pm 4.3 \mathrm{Nm}^{3}$ of biogas, on average $\left(18.3-32.2 \mathrm{Nm}^{3} / \mathrm{m}^{3}\right)$.

It should be also noticed that dried distillery spent wash was periodically added to digesters with the average amount of $15-20 \mathrm{~m}^{3} / \mathrm{d}$. However, mainly due to its lower biogas potential, as compared to fat waste, its application as a co-substrate was discontinued. This confirms the findings presented in the literature that the co-digestion process is usually conducted using a two-substrate mixture. Nevertheless, Grosser et al. [55] reported a beneficial effect of anaerobic co-digestion of sewage sludge, fat waste as well as OFMSW. In the presence of fat waste, the VS removal was increased from $50 \%$ to $56.4 \%$. Moreover, the methane yield was enhanced by $52 \%$, as compared to mono-digestion. Therein, the average methane yield reached the level of $0.45 \mathrm{Nm}^{3} / \mathrm{kg}$ VS. Introducing an additional co-substrate resulted in a further improvement of the digestion process. In relation to the mono-digestion of sewage sludge, the biogas yield increased by $82 \%$ (from 0.300 to $0.547 \mathrm{Nm}^{3} / \mathrm{kg}$ VS), while the VS removal improved by $29 \%$ (from $50 \%$ to $64.7 \%$ ). However, the application of co-substrates had no significant 
influence on the methane content in biogas, which amounted to $67-69 \%$, regardless of the mixture composition [55].

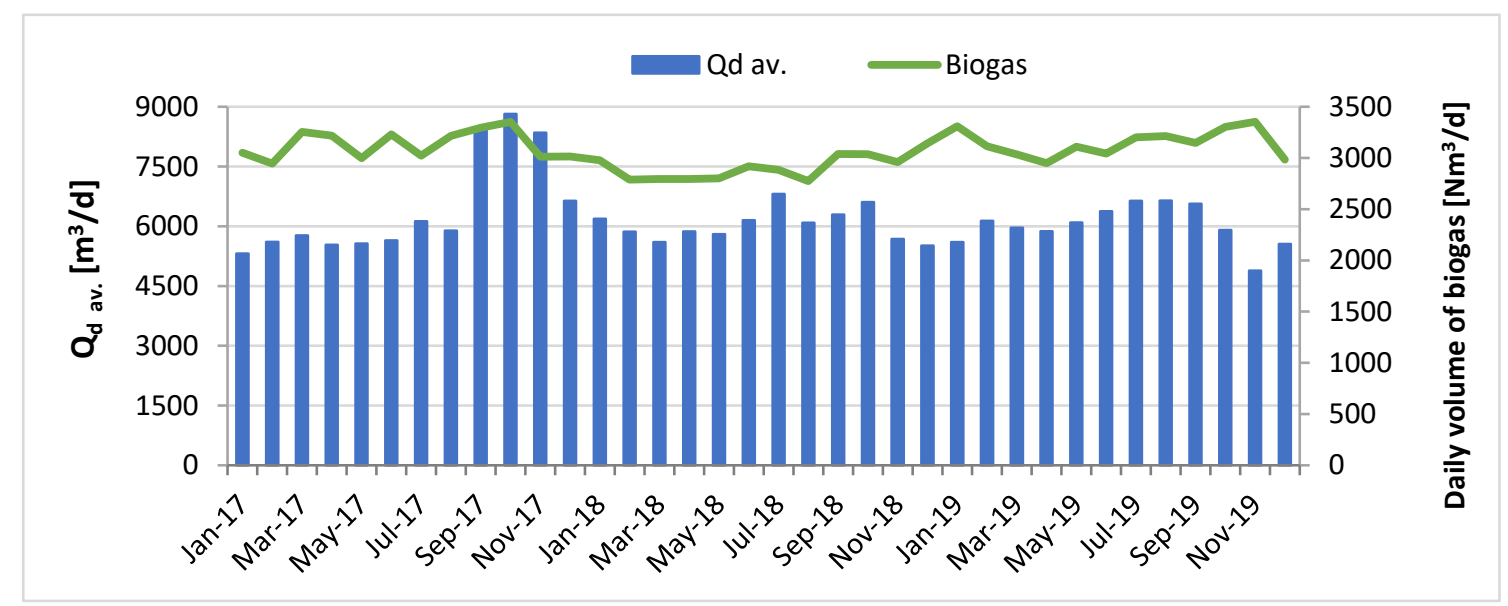

Figure 9. Daily biogas production vs. the wastewater flow in the WWTP.

The poultry industry wastes are often used as components in co-digestion with sewage sludge. Their biogas potential is highly diversified and may reach $0.57 \mathrm{Nm}^{3} / \mathrm{kg}$ VS [77], $0.61 \mathrm{Nm}^{3} / \mathrm{kg} \mathrm{VS}_{\text {[78], }}$ $0.631 \mathrm{Nm}^{3} / \mathrm{kg}$ VS [79], even up to $1.24 \mathrm{Nm}^{3} / \mathrm{kg}$ VS [80]. At the WWTP in Koziegłowy (Poland) $(1,200,000 \mathrm{PE})$, the poultry industry waste addition increased the yield of biogas by up to $30 \%$ (from 0.38 to $\left.0.49 \mathrm{Nm}^{3} / \mathrm{kg} \mathrm{VS}\right)$ at OLR $=1.66 \mathrm{~kg} \mathrm{VS} /\left(\mathrm{m}^{3} \cdot \mathrm{d}\right)$. The maximum share of this waste amounted to $13 \%$, in relation to the total mass of the digested mixture [80]. The comparison of biogas yield and the amount of added waste fat confirm the beneficial effect of this substrate on the course of digestion. A statistically significant dependence was noted between the share of waste fat and biogas yield (Figure 10).

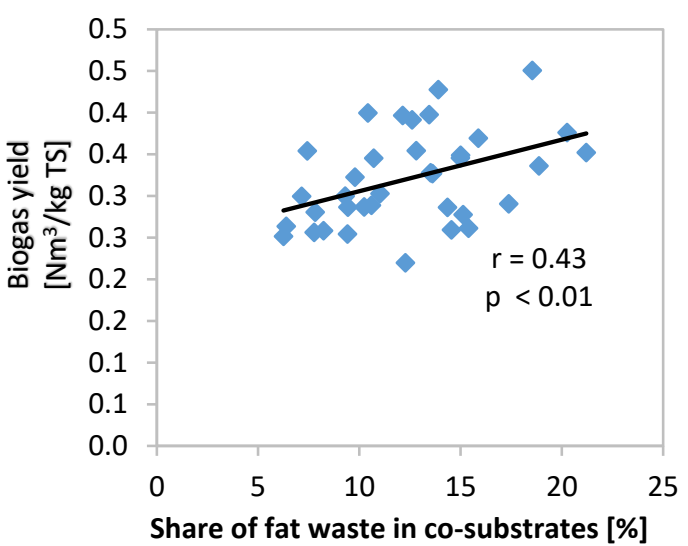

(a)

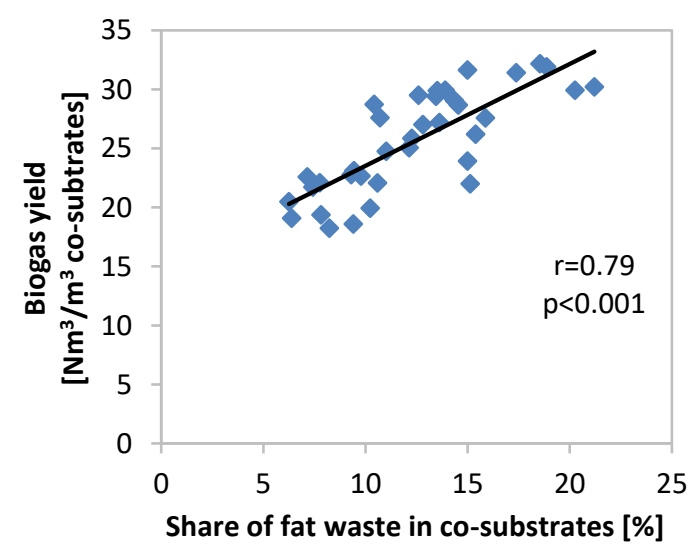

(b)

Figure 10. Influence of waste fat share in the digested mass on the biogas yield. Dependence between the share of waste fat and (a) biogas yield, (b) volumetric biogas yield.

The obtained biogas yield data can be compared with those from other Polish WWTPs employing the co-digestion of sewage sludge and various substrates. In the Rzeszów WWTP (398,000 PE), the feedstock was supplemented by waste fat (edible fat, spent cooking oils) and distillery decoction. Therein, the biogas yield ranged from 0.252 to $0.519 \mathrm{Nm}^{3} / \mathrm{kg}$ TS of sludge [81]. In the WWTP in Mielec $(85,750 \mathrm{PE})$, the ice-cream production wastes were added to digesters. In this case, in the presence 
of a co-substrate, a significant increase of $80-100 \%$ in biogas yield was observed. This parameter reached $19.9 \mathrm{Nm}^{3} / \mathrm{m}^{3}$ during co-digestion, while for the mono-digestion of sewage sludge, it was only $9.6 \mathrm{Nm}^{3} / \mathrm{m}^{3}$ [82].

Another example of a successful implementation of the co-fermentation strategy concerned the use of fat waste from fish processing at the Swarzewo WWTP (90,000 PE). In this case, the biogas yield was increased up to $80 \%$.

The fish waste, added in the amount of $1000 \mathrm{~kg}$ as a co-substrate, contributed to the generation of an additional $107 \mathrm{Nm}^{3}$ of biogas [83]. In turn, in the Krosno WWTP (117,000 PE), the co-fermentation of sewage sludge with an organic fraction of municipal wastes was performed. Therein, biogas production was achieved at the level of $11.2 \mathrm{Nm}^{3}$ of biogas per $1 \mathrm{~m}^{3}$ of the feedstock [84].

The statistical analysis of the results indicated that the daily biogas yield was significantly related with the $\mathrm{BOD}_{5}$ load in the influent and OLR (Figure 11). A strong correlation was observed between $\mathrm{BOD}_{5}$ in the influent $(\mathrm{r}=0.948, p<0.001)$ and the biogas yield (Figure 11a) as well as between the amount of co-substrates and the volumetric biogas yield (Figure 11b). The biogas yield in the plant ranged from 0.465 to $0.976 \mathrm{Nm}^{3} / \mathrm{kg} \mathrm{BOD}_{5}$ removed (mean $0.694 \mathrm{Nm}^{3} / \mathrm{kg} \mathrm{BOD}_{5}$ removed); the highest co-digestion efficiency was obtained at the BOD load of $2900-3300 \mathrm{~kg} \mathrm{O}_{2} / \mathrm{d}$. The yield of biogas depended on the OLR of the digester $(r=0.953, p<0.001)$ (Figure 11c). The highest biogas yield was observed at OLR $=1.7-2.0 \mathrm{~kg} \mathrm{TS} /\left(\mathrm{m}^{3} \cdot \mathrm{d}\right)$. In turn, the dependence between the daily biogas yield and digester OLR was moderate $(r=0.43, p<0.01)$ (Figure 11d).

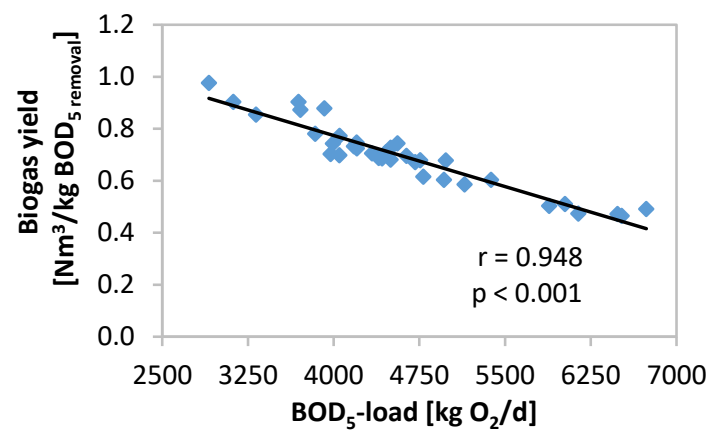

(a)

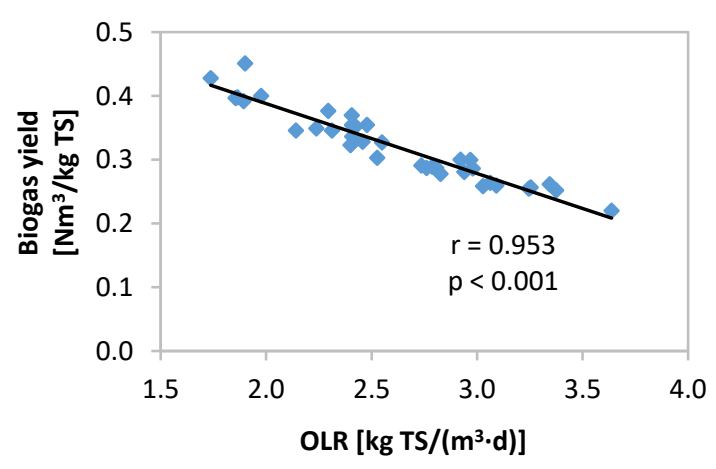

(c)

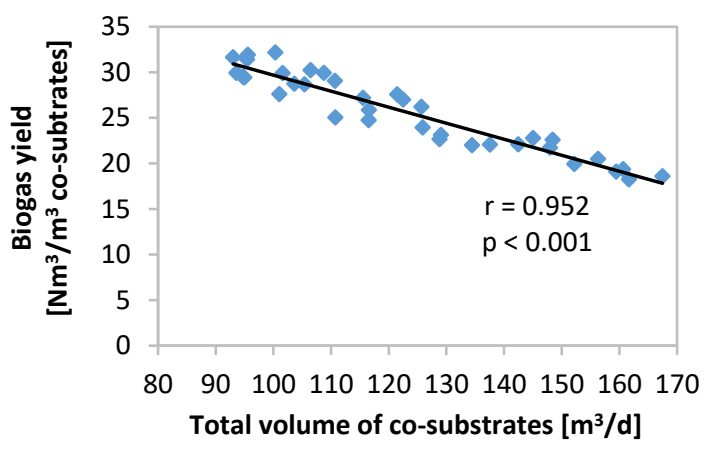

(b)

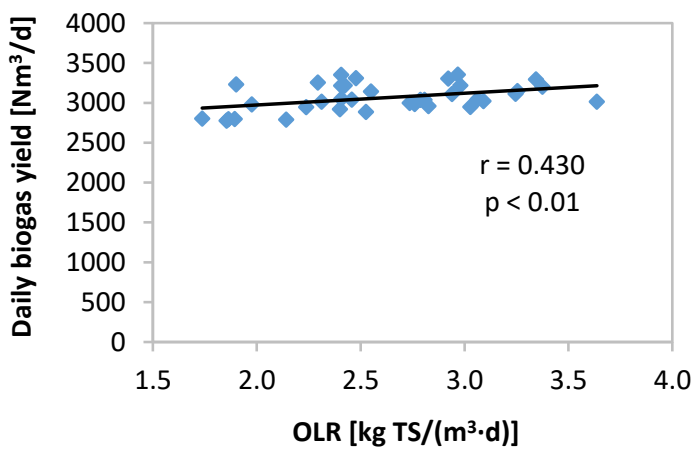

(d)

Figure 11. Influence of technological parameters on the daily biogas yield. Dependence between: (a) $\mathrm{BOD}_{5}$ in the influent and the biogas yield; (b) total volume of co-substrates and the volumetric biogas yield; (c) OLR of the digester and the biogas yield; (d) OLR of the digester and the daily biogas yield.

The assessment of the biogas-energy system of a WWTP usually involves the analysis of production and demand of energy of the WWTP. That allows for considering such facility as a combined technological and energetic system. In the analyzed WWTP, the monthly electricity consumption 
ranged from 172.7 to $229.83 \mathrm{MWh} / \mathrm{month}$. The energy intensity of the WWTP in Iława was estimated on the basis of the power consumption as well as the flow of wastewater and $\mathrm{BOD}_{5}$ load removed in technological processes. It amounted to $1.06 \mathrm{kWh} / \mathrm{m}^{3}\left(0.812-1.37 \mathrm{kWh} / \mathrm{m}^{3}\right)$ and $1.46 \mathrm{kWh} / \mathrm{kg} \mathrm{BOD}$ $\left(0.92-2.13 \mathrm{kWh} / \mathrm{BOD}_{5}\right)$ (Figure 12), on average. While comparing the results with those reported in literature, the energy intensity of the Iława WWTP can be considered as moderate. According to Maktabifard et al. [20], the unit energy consumption of the plant ranges from 0.26 to $1.11 \mathrm{kWh} / \mathrm{m}^{3}$. In turn, the report of the Polish Waterworks Chamber of Commerce established the energy-intensity index for the Polish WWTPs at $0.71-1.04 \mathrm{kWh} / \mathrm{m}^{3}$ (data for 2017) [69]. In the selected Polish WWTPs, the energy intensity is as follows: the Rzeszów WWTP-from 1.03 to $1.57 \mathrm{kWh} / \mathrm{BOD}_{5}$ and $0.865 \mathrm{kWh} / \mathrm{m}^{3}$ [85], the Krosno WWTP-0.61-1.11 kWh $/ \mathrm{m}^{3}$ [84], the Opole WWTP-0.723 kWh $/ \mathrm{m}^{3}$ and $1.66 \mathrm{kWh} / \mathrm{BOD}_{5}$ [86].

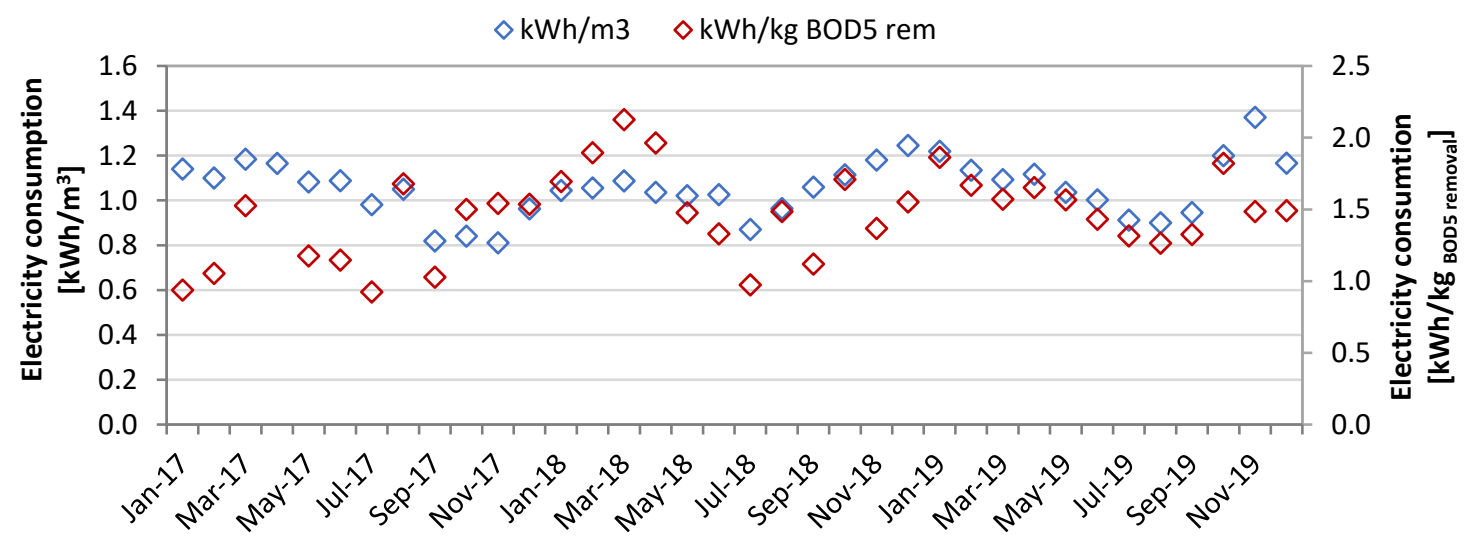

Figure 12. Energy intensity of the WWTP in Iława.

In the Iława WWTP, a significant amount of the generated biogas was used for the production of electricity. From January 2017 to September 2019, three CHP generators produced 7.63 GWh of electricity, with the mean annual value of $2.54 \mathrm{GWh}$. However, the monthly electricity production was diversified, ranging from 177.7 MWh (February 2018) to 236.1 MWh (October 2017), which also affected the operation of the three CHP generators. The greatest amount of electricity was produced in the autumn months (September-October). The unit electricity production ranged from 2.15 to $2.41 \mathrm{kWh} / \mathrm{Nm}^{3}$ biogas, with a mean value of $2.27 \pm 0.07 \mathrm{kWh} / \mathrm{Nm}^{3}$. As compared to other Polish WWTPs, the efficiency of electricity production in the Ilawa WWTP can be considered as significant. For example, this parameter amounted to $1.9-4.8 \mathrm{kWh} / \mathrm{Nm}^{3}$ in the Mielec WWTP [82], 3.82-4.51 $\mathrm{kWh} / \mathrm{Nm}^{3}$ in the Krosno WWTP) [84], 2.02-2.48 in the Rzeszów WWTP [83], 0.36-2.13 in the Dębica WWTP [87], 1.16-2.21 kWh/ $/ \mathrm{Nm}^{3}$ biogas in the Zamość WWTP [88], and 0.95-2.18 kWh/ $/ \mathrm{Nm}^{3}$ biogas in the Opole WWTP [84]. In turn, the estimated electricity recovery from wastewater amounted to $1.15 \mathrm{kWh} / \mathrm{m}^{3}$. In the analyzed period, the operation of CHP generators enabled covering the electricity demand $93.0 \%$ to $99.8 \%$. The self-sufficiency level of the Ilawa WWTP in 2017-2019 amounted to 98.2\% (Figure 13). Compared to other Polish WWTPs, the analyzed plant indicated a significant potential for energy production. The electricity demand in other Polish WWTPs achieved the following values: $35 \%$-the Opole WWTP [86], 46.5\%-the Dębica WWTP [87], 52.2\%-the Zamość WWTP [88], 74.3\%-the Rzeszów WWTP [85]. In Poland, there are several energy neutral WWTPs, i.e., the Tychy-Urbanowice WWTP, the Swarzewo WWTP, and the Słupsk WWTP, in which the electricity production from biogas exceeds $100 \%$ of the total electricity consumption in the plant [69].

Along with an increase of biogas production as well as the related electricity and thermal energy generation, a growth in the plant self-sufficiency-in relation to the power demand-was noted. This resulted from the modernization of the Iława WWTP, which has been performed since 2006 and contributed to achieving the self-sufficiency of the facility. The application of the co-digestion process was one of the directions, which resulted in a systematic increase in the production of electricity 
and thermal energy. The application of co-substrates led to an increase in the energy production by $50 \%$ (Figure 14). The total cost of the consecutive modernization that contributed to achieving self-sufficiency was approximated as 5.5 million euro. Importantly, the application of renewable energy produced based on sludge also resulted in a reduced emission of pollutants to the environment, in relation to a conventional coal-fired plant. The sustainable production of electricity in 2017-2019 enabled avoiding the emission of $5836 \mathrm{Mg} \mathrm{CO}_{2}$ and $274.7 \mathrm{PM}$ (estimated on the basis of the data of National Center for Emissions Management [89], which is a significant ecological effect.

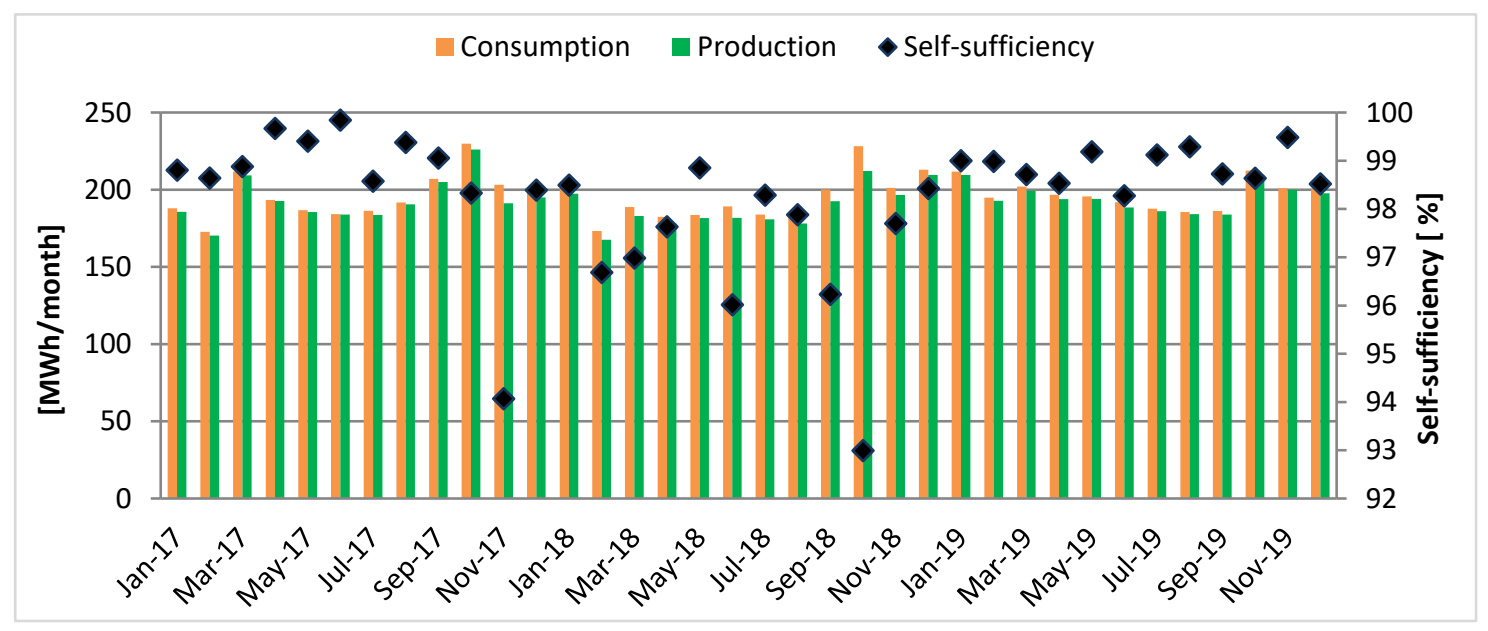

Figure 13. Energy balance at the Iława WWTP.

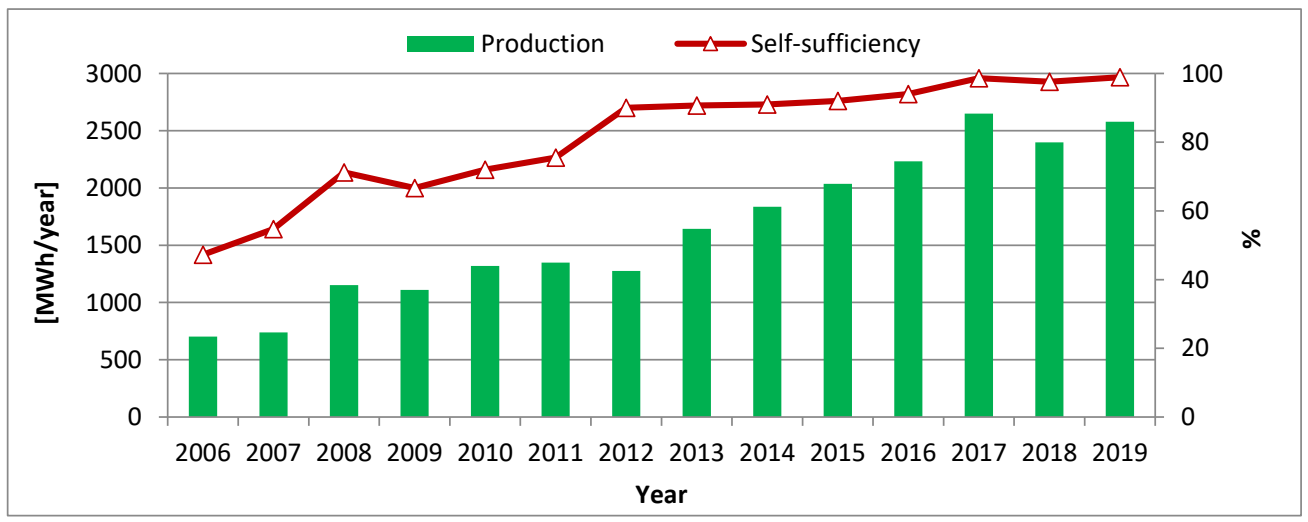

Figure 14. Energy balance for the Iława WWTP.

\section{Conclusions}

The biogas generated during the anaerobic digestion of sewage sludge is a valuable source of renewable energy, which may improve the energy balance of a facility. Simultaneously, the mentioned process reduced the operational costs and the emission of pollutants compared to the combustion of conventional fuels, e.g., hard coal. Achieving a full self-sufficiency in terms of energy demand in WWTPs is possible through the implementation of a highly efficient anaerobic digestion. One of the possibilities is the addition of co-substrates characterized by a significant fat content with relatively high biogas potential as well as favorable composition of sewage sludge. An example of an effective application of this strategy is the WWTP in Iława. On the basis of the analysis, the authors showed that as a result of the co-digestion of sewage sludge and poultry processing wastes, the production of a total of $7.63 \mathrm{GWh}$ of electricity, with a mean annual amount of $2.54 \mathrm{GWh}$, was recorded. That allowed covering the energy demand in a significant degree, ranging from $93.0 \%$ to $99.8 \%$ (mean value of 
98.2\%). The actions taken by the authors have shown that the strategy in the Iława WWTP allows utilizing the unused potential of fermentation chambers for the production of clean energy.

Importantly, in the presence of a co-substrate, the removal efficiency of AD was improved. An enhancement from $64 \%$ (mono-digestion) to $69-70 \%$ (co-digestion) was found.

Additionally, the AcoD technology contributed to successful waste management, thus bringing benefits for both the WWTP and the poultry company.

The considerations undertaken by the authors are of a multi-faceted analysis of the sludge management and the biogas and energy system in the wastewater treatment plant. This publication provides innovative information pertaining to renewable energy in the wastewater industry so that wastewater treatment plants can use their own resources, in this case sewage sludge, and obtain savings related to their own energy production.

Author Contributions: Conceptualization and methodology, A.M., J.C. and G.Ł.; formal analysis, G.Ł.; investigation, resources, data curation and visualization, A.M., J.C.; writing-original draft preparation, A.M., J.C.; writing-review and editing, A.S., J.S.-C. and G.E.; All authors have read and agreed to the published version of the manuscript.

Funding: This work was financially supported within the statutory research of particular scientific units under subvention for a science program.

Acknowledgments: The kind help from Iława WWTP staffs gratefully acknowledged.

Conflicts of Interest: The authors declare no conflict of interest.

\section{Abbreviations}

$\begin{array}{ll}\text { AcoD } & \text { anaerobic co-digestion process } \\ \text { AD } & \text { anaerobic digestion } \\ \text { BOD }_{5} & \text { Biochemical Oxygen Demand } \\ \text { CHP } & \text { combined heat and power } \\ \text { ES } & \text { excess sludge } \\ \text { FOG } & \text { fat, oil, and grease wastes } \\ \text { HRT } & \text { hydraulic retention time } \\ \text { LCFA } & \text { long-chain fatty acids } \\ \text { MW } & \text { megawatts electric } \\ \text { OFMSW } & \text { organic fraction of municipal solid waste } \\ \text { OLR } & \text { organic loading rate } \\ \text { PE } & \text { population equivalent } \\ \text { PS } & \text { population equivalent } \\ \text { TS } & \text { total solids content } \\ \text { VS } & \text { volatile solids } \\ \text { WWTP } & \text { wastewater treatment plant }\end{array}$

\section{References}

1. Di Fraia, S.; Massarotti, N.; Vanoli, L. A novel energy assessment of urban wastewater treatment plants. Energy Convers. Manag. 2018, 163, 304-313. [CrossRef]

2. Masłoń, A.; Wójcik, M.; Chmielowski, K. Efficient use of energy in wastewater treatment plants. Energy Policy Stud. 2018, 1, 12-26.

3. Roots, P.; Sabba, F.; Rosenthal, A.F.; Wang, Y.; Yuan, Q.; Rieger, L.; Yang, F.; Kozak, J.A.; Zhang, H.; Wells, G.F. Integrated shortcut nitrogen and biological phosphorus removal from mainstream wastewater: Process operation and modeling. Environ. Sci. Water Res. Technol. 2020, 6, 566-580. [CrossRef]

4. Wang, B.; Guo, Y.; Zhao, M.; Li, B.; Peng, Y. Achieving Energy-Efficient Nitrogen Removal and Excess Sludge Reutilization by Partial Nitritation and Simultaneous Anammox Denitrification and Sludge Fermentation Process. Chemosphere 2019, 218, 705-714. [CrossRef] [PubMed]

5. Czarnota, J.; Masłoń, A.; Zdeb, M.; Łagód, G. The impact of different powdered mineral materials on selected properties of aerobic granular sludge. Molecules 2020, 25, 386. [CrossRef] 
6. Drewnowski, J.; Mąkinia, J.; Szaja, A.; Łagód, G.; Kopeć, Ł.; Aguilar, J.A. Comparative Study of Balancing SRT by Using Modified ASM2d in Control and Operation Strategy at Full-Scale WWTP. Water 2019, 11, 485. [CrossRef]

7. Drewnowski, J.; Remiszewska-Skwarek, A.; Duda, S.; Łagód, G. Aeration Process in Bioreactors as the Main Energy Consumer in a Wastewater Treatment Plant. Review of Solutions and Methods of Process Optimization. Processes 2019, 7,311. [CrossRef]

8. Szelag, B.; Drewnowski, J.; Łagód, G.; Majerek, D.; Dacewicz, E.; Fatone, F. Soft Sensor Application in Identification of the Activated Sludge Bulking Considering the Technological and Economical Aspects of Smart Systems Functioning. Sensors 2020, 20, 1941. [CrossRef]

9. Silvestre, G.; Fernández, B.; Bonmatí, A. Significance of anaerobic digestion as a source of clean energy in wastewater treatment plants. Energy Convers. Manag. 2015, 101, 255-262. [CrossRef]

10. De Vrieze, J.; Smet, D.; Klok, J.; Colsen, J.; Angenent, L.T.; Vlaeminck, S.E. Thermophilic sludge digestion improves energy balance and nutrient recovery potential in full-scale municipal wastewater treatment plants. Bioresour. Technol. 2016, 218, 1237-1245. [CrossRef]

11. Wu, N.; Moreira, C.; Zhang, Y.; Doan, N.; Yang, S.; Phlips, E.; Svoronos, S.; Pullammanappallil, P. Techno-Economic Analysis of Biogas Production from Microalgae through Anaerobic Digestion. In Anaerobic Digestion; Banu, J.R., Ed.; IntechOpen: London, UK, 2019. [CrossRef]

12. Pellera, F.; Gidarakos, E. Anaerobic digestion of solid agroindustrial waste in semi-continuous mode: Evaluation of mono-digestion and co-digestion systems. Waste Manag. 2017, 68, 103-119. [CrossRef] [PubMed]

13. Guo, W.Q.; Yang, S.S.; Xiang, W.S.; Wang, X.J.; Ren, N.Q. Minimization of excess sludge production by in-situ activated sludge treatment processes - A comprehensive review. Biotechnol. Adv. 2013, 31, 1386-1396. [CrossRef] [PubMed]

14. Neczaj, E.; Grosser, A. Circular Economy in Wastewater Treatment Plant-Challenges and Barriers. Proceedings 2018, 2, 614. [CrossRef]

15. Mata-Álvares, J.; Dosta, J.; Romero-Güiza, M.S.; Fonoll, X.; Peces, M.; Astals, S. A critical review on anaerobic co-digestion achievements between 2010 and 2013. Renew. Sustain. Energy Rev. 2014, 36, 412-427. [CrossRef]

16. Rabii, A.; Aldin, S.; Dahman, Y.; Elbeshbishy, E. A review on anaerobic co-digestion with a focus on the microbial populations and the effect of multi-stage digester configuration. Energies 2019, 12, 1106. [CrossRef]

17. Alrawashdeh, K.A.B.; Pugliese, A.; Slopiecka, K.; Pistolesi, V.; Massoli, S.; Bartocci, P.; Bidini, G.; Fantozzi, F. Codigestion of untreated and treated sewage sludge with the organic fraction of municipal solid wastes. Fermentation 2017, 3, 35. [CrossRef]

18. Xie, S.; Wickham, R.; Nghiem, L.D. Synergistic effect from anaerobic co-digestion of sewage sludge and organic wastes. Int. Biodeterior. Biodegrad. 2017, 116, 191-197. [CrossRef]

19. Di Capua, F.; Spasiano, D.; Giordano, A.; Adani, F.; Fratino, U.; Pirozzi, F.; Esposito, G. High-solid anaerobic digestion of sewage sludge: Challenges and opportunities. Appl. Energy 2020, 278, 115608. [CrossRef]

20. Maktabifard, M.; Zaborowska, E.; Makinia, J. Achieving energy neutrality in wastewater treatment plants through energy savings and enhancing renewable energy production. Rev. Environ. Sci. Biotechnol. 2018, 17, 655-689. [CrossRef]

21. Longo, S.; d'Antoni, B.M.; Bongards, M.; Chaparro, A.; Cronrath, A.; Fatone, F.; Lema, J.M.; Mauricio-Iglesias, M.; Soares, A.; Hospido, A. Monitoring and diagnosis of Energy consumption in wastewater treatment plants. A state of the art and proposals for improvement. Appl. Energy 2016, 176, 1251-1268. [CrossRef]

22. Kiselev, A.; Magaril, E.; Magaril, R.; Panepinto, D.; Ravina, M.; Zanetti, M.C. Towards Circular Economy: Evaluation of Sewage Sludge Biogas Solutions. Resources 2019, 8, 91. [CrossRef]

23. Liu, Y.; Huang, T.; Li, X.; Huang, J.; Peng, D.; Maurer, C.; Kranert, M. Experiments and Modeling for Flexible Biogas Production by Co-Digestion of Food Waste and Sewage Sludge. Energies 2020, 13, 818. [CrossRef]

24. Spellman, F.R. Water $\mathcal{E}$ Wastewater Infrastructure: Energy Efficiency and Sustainability, 1st ed.; CRC Press: Boca Raton, FL, USA, 2013; pp. 1-463.

25. Orchowski, M.; Masłon, A.; Heidrich, Z. Energy consumption of the Sandomierz wastewater treatment plant. Gas Water Sanit. Eng. 2018, 2, 72-77. [CrossRef]

26. Bodík, I.; Kubaská, M. Energy and sustainability of operation of a wastewater treatment plant. Environ. Protect. Eng. 2013, 39, 15-24. [CrossRef]

27. Tyagi, V.K.; Lo, S.L. Sludge: A waste or renewable source for energy and resources recovery? Renew. Sustain. Energy Rev. 2013, 25, 708-728. [CrossRef] 
28. Koniuszewska, I.; Korzeniewska, E.; Harnisz, M.; Czatzkowska, M. Intensification of biogas production using various technologies: A review. Int. J. Energy Res. 2020, 44, 6240-6258. [CrossRef]

29. Dymaczewski, Z.; Szulc, P. The modern wastewater treatment plant in the concept of sustainable development. In Proceedings of the Technical Conference "Innovative Solutions in Wastewater Treatment and Sludge Management", Piła, Poland, 10-11 October 2017.

30. Caposciutti, G.; Baccioli, A.; Ferrari, L.; Desideri, U. Biogas from Anaerobic Digestion: Power Generation or Biomethane Production? Energies 2020, 13, 743. [CrossRef]

31. Parsons, D.; Marcet, E.C.; Jeffrey, P. Carbon Sensitive Urban Water Futures. D 21.1; E.U: Tansitions to the Urban Water Services of Tomorrow (TRUST), 2012. Available online: https://ita.upv.es/TRUST/downloads/index. php?iddesc $=1$ (accessed on 16 June 2020).

32. Shen, Y.; Linville, J.L.; Urgun-Demirtas, M.; Mintz, M.M.; Snyder, S.W. An overview of biogas production and utilization at full-scale wastewater treatment plants (WWTPs) in the United States: Challenges and opportunities towards energy-neutral WWTPs. Renew. Sustain. Energy Rev. 2015, 50, 346-362. [CrossRef]

33. Dzene, I.; Slotina, L. Efficient Heat Use from Biogas CHP Plants. Case Studies from Biogas Plants in Latvia. Environ. Clim. Technol. 2013, 3, 45-48. [CrossRef]

34. Awe, O.W.; Zhao, Y.; Nzihou, A.; Minh, D.P.; Lyczko, N. A review of biogas utilization, purification and upgrading technologies. Waste Biomass Valori. 2017, 8, 267-283. [CrossRef]

35. Grosser, A.; Neczaj, E. Sewage sludge and fat rich materials co-digestion-Performance and energy potential. J. Clean. Prod. 2018, 198, 1076-1089. [CrossRef]

36. Chow, W.L.; Chong, S.; Lim, J.W.; Chan, Y.J.; Chong, M.F.; Tiong, T.J.; Chin, J.K.; Pan, G.-T. Anaerobic Co-Digestion of Wastewater Sludge: A Review of Potential Co-Substrates and Operating Factors for Improved Methane Yield. Processes 2020, 8, 39. [CrossRef]

37. Szaja, A.; Montusiewicz, A. Enhancing the co-digestion efficiency of sewage sludge and cheese whey using brewery spent grain as an additional substrate. Bioresour. Technol. 2019, 291, 121863. [CrossRef] [PubMed]

38. Zhen, G.; Lu, X.; Kato, H.; Zhao, Y.; Li, Y.Y. Overview of pretreatment strategies for enhancing sewage sludge disintegration and subsequent anaerobic digestion: Current advances, full-scale application and future perspectives. Renew. Sustain. Energy Rev. 2017, 69, 559-577. [CrossRef]

39. Choi, J.-M.; Han, S.-K.; Lee, C.-Y. Enhancement of methane production in anaerobic digestion of sewage sludge by thermal hydrolysis pretreatment. Biores. Technol. 2018, 259, 207-213. [CrossRef] [PubMed]

40. Svensson, K.; Kjørlaug, O.; Higgins, M.J.; Linjordet, R.; Horn, S. Post-anaerobic digestion thermal hydrolysis of sewage sludge and food waste: Effect on methane yields, dewaterability and solids reduction. Wat. Res. 2018, 132, 158-166. [CrossRef]

41. Yang, D.; Hu, C.; Dai, L.; Liu, Z.; Dong, B.; Dai, X. Post-thermal hydrolysis and centrate recirculation for enhancing anaerobic digestion of sewage sludge. Waste Manag. 2019, 92,39-48. [CrossRef]

42. Grübel, K.; Wacławek, S.; Kuglarz, M.; Wacławek, M.; Černík, M. Improvement of the thermophilic anaerobic digestion and hygienisation of waste activated sludge by synergistic pretreatment. J. Environ. Sci. Health-Part A Toxic/Hazardous Subst. Environ. Eng. 2019, 54, 694-700. [CrossRef]

43. Waclawek, S.; Grübel, K.; Silvestri, D.; Padil, V.V.T.; Waclawek, M.; Cerník, M.; Varma, R.S. Disintegration of wastewater activated sludge (WAS) for improved biogas production. Energies 2019, 12, 21. [CrossRef]

44. Xie, S.; Higgins, M.J.; Bustamante, H.; Galway, B.; Nghiem, L.D. Current status and perspectives on anaerobic co-digestion and associated downstream processes. Environ. Sci. Water Res. Technol. 2018, 4, 1759-1770. [CrossRef]

45. Widomski, M.K. Selected methods of water resources accounting in the aspect of sustainable development. Probl. Ekorozw./Probl. Sustain. Dev. 2014, 9, 141-150.

46. Pawłowski, A.; Pawłowski, L. Impact of energy acquisition methods on the implementation of sustainable development paradigms (In Polish). Rocz. Ochr. Sr. 2016, 18, 19-37.

47. Werle, S. Sewage Sludge-To-Energy Management in Eastern Europe: A Polish Perspective. Ecol. Chem. Eng. S 2015, 22, 459-469. [CrossRef]

48. Siddique, M.N.I.; Wahid, Z.A. Achievements and perspectives of anaerobic co-digestion: A review. J. Clean. Prod. 2018, 194, 359-371. [CrossRef]

49. Cano, R.; Pérez-Elvira, S.I.; Fdz-Polanco, F. Energy feasibility study of sludge pretreatments: A review. Appl. Energy 2015, 149, 176-185. [CrossRef] 
50. Silvestre, G.; Rodríguez-Abalde, A.; Fernández, B.; Flotats, X.; Bonmatí, A. Biomass adaptation over anaerobic co-digestion of sewage sludge and trapped grease waste. Bioresour. Technol. 2011, 102, 6830-6836. [CrossRef]

51. Astals, S.; Esteban-Gutiérrez, M.; Fernández-Arévalo, T.; Aymerich, E.; García-Heras, J.L.; Mata-Alvarez, J. Anaerobic digestion of seven different sewage sludges: A biodegradability and modelling study. Water Res. 2013, 47, 6033-6043. [CrossRef]

52. Bulak, P.; Proc, K.; Pawłowska, M.; Kasprzycka, A.; Berus, W.; Bieganowski, A. Biogas generation from insects breeding post production wastes. J. Clean. Prod. 2020, 244, 118777. [CrossRef]

53. Zubrowska-Sudol, M.; Dzido, A.; Garlicka, A.; Krawczyk, P.; Stępień, M.; Umiejewska, K.; Walczak, J.; Wołowicz, M.; Sytek-Szmeichel, K. Innovative Hydrodynamic Disintegrator Adjusted to Agricultural Substrates Pre-treatment Aimed at Methane Production Intensification-CFD Modelling and Batch Tests. Energies 2020, 13, 4256. [CrossRef]

54. Drzewicki, A.; Bułkowska, K.; Tomczykowska, M. Intensification of the biomethanisation process in wastewater treatment plant. Int. J. Environ. Res. 2015, 9, 805-812. [CrossRef]

55. Grosser, A.; Neczaj, E.; Singh, B.R.; Almås, R.; Brattebø, H.; Kacprzak, M. Anaerobic digestion of sewage sludge with grease trap sludge and municipal solid waste as co-substrates. Environ. Res. 2017, 155, 249-260. [CrossRef] [PubMed]

56. Long, J.H.; Aziz, T.N.; Reyes, F.L.D.L.; Ducoste, J.J. Anaerobic co-digestion of fat, oil, and grease (FOG): A review of gas production and process limitations. Process. Saf. Environ. Prot. 2012, 90, 231-245. [CrossRef]

57. Palatsi, J.; Laureni, M.; Andrés, M.V.; Flotats, X.; Nielsen, H.B.; Angelidaki, I. Strategies for recovering inhibition caused by long chain fatty acids on anaerobic thermophilic biogas reactors. Bioresour. Technol. 2009, 100, 4588-4596. [CrossRef] [PubMed]

58. Zonta, Ž.; Alves, M.M.; Flotats, X.; Palatsi, J. Modelling inhibitory effects of long chain fatty acids in the anaerobic digestion process. Water Res. 2013, 47, 1369-1380. [CrossRef]

59. Davidsson, Å.; Lövstedt, C.; la Cour Jansen, J.; Gruvberger, C.; Aspegren, H. Co-digestion of grease trap sludge and sewage sludge. Waste Manag. 2008, 28, 986-992. [CrossRef]

60. Kalemba, K.; Barbusiński, K. Anaerobic co-digestion of sewage sludge and molasses. In Proceedings of the International Conference on Advances in Energy Systems and Environmental Engineering (ASEE17), E3S Web Conf, Wrocław, Poland, 2-5 July 2017; Volume 22, p. 00075. [CrossRef]

61. MosayebNezhad, M.; Mehr, A.S.; Gandiglio, M.; Lanzini, A.; Santarelli, M. Techno-economic assessment of biogas-fed CHP hybrid systems in a real wastewater treatment plant. Appl. Therm. Eng. 2018, 129, 1263-1280. [CrossRef]

62. Central Statistical Office of Poland (GUS). 2019. Available online: http://www.gus.pl/ (accessed on 6 August 2020).

63. Council Directive 86/278/EEC of 12 June 1986 on the Protection of the Environment, and in Particular of the Soil, When Sewage Sludge Is Used in Agriculture. Available online: https://eur-lex.europa.eu/ (accessed on 10 June 2020).

64. Council Directive 91/271/EEC of 21 May 1991 Concerning Urban Waste-Water Treatment. Available online: https://eur-lex.europa.eu/ (accessed on 10 June 2020).

65. Council Directive 1999/31/EC of 26 April 1999 on the Landfill of Waste. Available online: https://eur-lex. europa.eu/ (accessed on 10 June 2020).

66. Directive 2000/76/EC of the European Parliament and of the Council of 4 December 2000 on the Incineration of Waste. Available online: https://eur-lex.europa.eu/ (accessed on 10 June 2020).

67. Sun, Y.; Lu, M.; Sun, Y.; Chen, Z.; Duan, H.; Liu, D. Application and Evaluation of Energy Conservation Technologies in Wastewater Treatment Plants. Appl. Sci. 2019, 9, 4501. [CrossRef]

68. Rzepecki, T. A self-sufficient water supply and sewage company-A dream or a real possibility. In Proceedings of the 4th Scientific Conference "Energy Security-Pillars and Development Perspective", Rzeszów, Poland, 1-2 April 2019.

69. Chamber of Commerce "Polish Waterworks" (IGWP). Information Materials. 2020. Available online: https://www.igwp.org.pl/ (accessed on 12 June 2020).

70. Durdevic, Đ.; Blecich, P.; Zelijko, J. Energy Recovery from Sewage Sludge: The Case. Study of Croatia. Energies 2019, 12, 1927. [CrossRef]

71. Polish Oil and Gas Company (PGNiG). Annual Report. 2019. Available online: http://http://en.pgnig.pl/ (accessed on 12 August 2020). 
72. BP Statistical Review of World Energy. 2019. Available online: https://www.bp.com/ (accessed on 10 August 2020).

73. German ATV-DVWK Rules and Standards ATV-DVWK-A 131, E. Dimensioning of Single-Stage Activated Sludge Plants. May 2000. Available online: https://kupdf.net/download/atv-dvwk-a-131e_ 58ff62c7dc0d60307d959e98_pdf (accessed on 12 June 2020).

74. Grosser, A. The influence of decreased hydraulic retention time on the performance and stability of co-digestion of sewage sludge with grease trap sludge and organic fraction of municipal waste. J. Environ. Manage. 2017, 203, 1143-1157. [CrossRef]

75. Björn, A.; ShakeriYekta, S.; Ziels, R.M.; Gustafsson, K.; Svenssom, B.H.; Karlsson, A. Feasibility of OFMSW co-digestion with sewage sludge for increasing biogas production at wastewater treatment plants. Euro-Mediterr. J. Environ. Integr. 2017, 2, 21. [CrossRef]

76. Koch, K.; Helmreich, B.; Drewes, J.E. Co-digestion of food waste in municipal wastewater treatment plants: Effect of different mixtures on methane yield and hydrolysis rate constant. Appl. Energy 2015, 137, 250-255. [CrossRef]

77. Yoon, Y.-M.; Kim, S.-H.; Oh, S.-Y.; Kim, C.-H. Potential of anaerobic digestion for material recovery and energy production in waste biomass from a poultry slaughterhouse. Waste Manag. 2014, 34, 204-209. [CrossRef] [PubMed]

78. Pitk, P.; Kaparaju, P.; Vilu, R. Methane potential of sterilized solid slaughterhouse wastes. Biores. Technol. 2012, 116, 42-46. [CrossRef]

79. Latifi, P.; Karrabi, M.; Danesh, S. Anaerobic co-digestion of poultry slaughterhouse wastes with sewage sludge in batch-mode bioreactors (effect of inoculum-substrate ratio and total solids). Renew. Sustain. Energ. Rev. 2019, 107, 288-296. [CrossRef]

80. Budych-Gorzna, M.; Smoczyński, M.; Oleskowicz-Popiel, P. Enhancement of biogas production at the municipal wastewater treatment plant by co-digestion with poultry industry waste. Appl. Energy 2016, 161, 387-394. [CrossRef]

81. Masłoń, A.; Tendera, K. Sewage sludge management at the Rzeszów WWTP. Forum Eksploatatora 2017, 1, 38-45. (In Polish)

82. Masłoń, A.; Pazdro, S.; Mroczek, W. Sewage sludge management in wastewater treatment plant in Mielec. Forum Eksploatatora 2015, 4, 47-54. (In Polish)

83. Gazda, M.; Rak, A.; Sudak, M. Research on cofermentation of sewage sludge with waste fats for the wastewater treatment plant in Brzeg. Infrastr. Ecol. Rural Ar. 2012, 3, 79-90. (In Polish)

84. Trojanowicz, K.; Karamus, Ł. Energy utilization of biogas as an element of sewage sludge management in the wastewater treatment plant in Krosno. Forum Eksploatatora 2016, 4, 46-53. (In Polish)

85. Masłoń, A. Analysis of energy consumption at the Rzeszów Wastewater Treatment Plant. In Proceedings of the International Conference on Advances in Energy Systems and Environmental Engineering (ASEE17), E3S Web Conf, Wrocław, Poland, 2-5 July 2017; Volume 22, p. 00115. [CrossRef]

86. Szczyrba, P.; Masłoń, A.; Czarnota, J.; Olszewski, K. Analysis of sewage sludge and biogas-energy management at the Opole wastewater treatment plant. Ecol. Eng. 2020, 21, 26-34. [CrossRef]

87. Masłoń, A.; Czarnota, J. Biogas production from sewage sludge as an energy balance element of the wastewater treatment plant. In Proceedings of the VI International Scientific and Technical Conference "Pure Water. Fundamental, Applied and Industrial Aspects", Kiev, Ukraine, 14-15 November 2019; pp. 46-48.

88. Masłoń, A. An Analysis of Sewage Sludge and Biogas Production at the Zamość WWTP. Lect. Notes Civ. Eng. 2020, 7, 291-298. [CrossRef]

89. Poland's National Inventory Report 2018; National Centre for Emission Management (KOBiZE) at the Institute of Environmental Protection-National Research Institute: Warsaw, Poland, 2018. Available online: http: //www.kobize (accessed on 2 September 2020).

Publisher's Note: MDPI stays neutral with regard to jurisdictional claims in published maps and institutional affiliations. 